\title{
Megaeventos esportivos e seus legados: uma análise dos efeitos institucionais da eleição do Brasil como país-sede
}

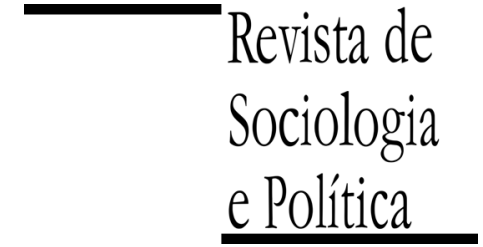

DOI 10.1590/1678-987315235602

\author{
Renata Maria Toledo, Jonathan Grix \\ e Maria Tarcisa Silva Bega
}

\section{Resumo}

Este trabalho visa a examinar os efeitos institucionais da realização da Copa do Mundo de 2014 e dos Jogos Olímpicos de 2016 no Brasil. Trata-se de analisar as mudanças jurídico-institucionais para atender às demandas das organizações esportivas internacionais que possuem o controle sobre o esporte de alto rendimento e os eventos a ele correlatos, de sorte a identificar eventuais impactos nas instituições do país-sede. Para a consecução desse objetivo, focamos as alterações legislativas efetuadas pelo governo federal brasileiro com vistas ao cumprimento das garantias financeiras, políticas e jurídicas apresentadas pelos comitês de candidatura à Fédération Internationale de Football Association (FIFA) e ao Comitê Olímpico Internacional (COI). Realizamos uma pesquisa documental, enfatizando os dispositivos legais com referência à matéria, entre os quais cabe destacar o Ato Olímpico, a Lei Geral da Copa e a lei que instituiu o Regime Diferenciado de Contratações Públicas (RDC), coligindo-os com a legislação prévia. Em seguida, com fundamento no neoinstitucionalismo sociológico e na tipologia de análise sobre o ambiente legal das organizações de Edelman \& Suchman (1997), procedemos à análise de seus efeitos institucionais, efetuando dois movimentos analíticos: (i) o exame da influência das organizações - esportivas e políticas - na produção legislativa; (ii) a discussão sobre como, e em que medida, as referidas alterações legislativas impactam as organizações, com ênfase na dimensão constitutiva do ambiente legal. Quanto ao primeiro, identificamos a ocorrência de legados institucionais na dimensão regulatória do ambiente legal, sendo que esse se deu de maneira normativa no que se refere ao Ato Olímpico e à Lei Geral da Copa e de modo cognitivo no tocante à lei que instituiu o RDC. Com respeito ao segundo, dado que os efeitos nessa dimensão não surgem de imediato, não foi possível verificar a ocorrência de efeitos institucionais nos discursos, práticas e procedimentos das organizações envolvidas no processo, o que sugeriu a necessidade de implementação de uma agenda de pesquisa que possa contemplar os eventuais legados institucionais sobre essa dimensão do ambiente legal. O resultado da pesquisa contribui com a literatura na medida em que lhe acrescenta uma nova diretriz metodológica e uma nova dimensão analítica. No que concerne à primeira, enquanto os estudos acadêmicos comumente se caracterizam por uma abordagem a posteriori, desenvolvemos em nosso estudo a noção de legados pré-eventos. No que se refere à segunda, propõe uma categoria de legados (institucionais) ainda inexplorada pela produção acadêmica sobre os legados de megaeventos esportivos. Ademais, sugere a constituição de uma agenda de pesquisas, a ser executada pelos pesquisadores dessa área.

PALAVRAS-CHAVE: megaeventos esportivos; legados; instituições; Copa do Mundo de 2014; Jogos Olímpicos de 2016.

Recebido em 5 de Maio de 2014. Aceito em 19 de Junho de 2014.

\section{Introdução ${ }^{1}$}

${ }^{1}$ Agradecemos os pareceristas anônimos da Revista de Sociologia e Política por seus comentários.
$\mathrm{O}$ aumento da saliência política do esporte, ao longo dos últimos 30 anos, é uma tendência social sobre a qual poucos analistas discordariam. Com efeito, o progressivo envolvimento dos governos com a formulação e implementação de políticas públicas de esporte, no interior das quais se destaca a tentativa de realização de megaeventos esportivos, denota um padrão histórico que se expandiu por diferentes países, tanto aqueles integrantes do núcleo central do sistema capitalista, quanto os chamados países "em desenvolvimento", "emergentes" ou mesmo pequenos Estados, que passaram a competir para sediar um evento esportivo de grande magnitude. Paralelamente, observamos o crescimento gradual de uma literatura acadêmica cujo foco se circunscreve no uso político do esporte, destinando especial atenção às razões 
subjacentes às candidaturas para sediar os referidos eventos bem como aos "legados" que os países visam a atingir por meio de sua realização (Chalip 2004; Horne 2007; Houlihan \& Green 2008; Weed et al., 2009; Manzenreiter 2010).

No tocante à discussão sobre legados de megaeventos esportivos, observamos a existência de uma literatura internacional bastante consolidada, que foi progressivamente sedimentada desde os fins da década de 1990, constituindo-se como uma subárea temática das pesquisas sobre os megaeventos. Tomando-a por base, observamos que os estudos acadêmicos sobre esse tópico se caracterizam, de um lado, por uma abordagem a posteriori, centrada na investigação de legados tangíveis, a exemplo da infraestrutura para a prática esportiva a ser disponibilizada para uso da população após o encerramento de um megaevento. Assim sendo, trata-se de uma perspectiva que opera com um cenário futuro. Por outro lado, focam as "estratégias de fomento" adotadas pelos países para lucrar o máximo possível com a sua organização (Chalip 2006). Em sua leitura identificamos, por vezes sobrepostos, cinco tipos ou categorias de legados, todos compreendendo alguma perspectiva de ganho econômico para o país/cidade anfitriã, a seguir enumerados:

- (i) Megaeventos esportivos podem inspirar as massas, incluindo os jovens, a praticar esporte ou outra forma de atividade física, de modo a aprimorar a saúde;

- (ii) Esses eventos são economicamente lucrativos, trazendo oportunidades para, entre outros aspectos, incrementar o turismo no país/cidade-sede;

- (iii) Megaeventos esportivos engendram um "fator de bem-estar" entre os cidadãos, de forma a produzir efeitos para o bem-estar geral da população no país em que o evento se realiza;

- (iv) A organização dos megaeventos acelera muito da regeneração urbana demandada pela cidade-sede, aprimorando a sociedade e "incluindo as cidades no mapa";

- (v) Megaeventos esportivos trazem benefícios para a imagem do país, uma vez que a exposição internacional gera um incremento do prestígio internacional, ou seja, alteram positivamente o modo como o país/cidade-sede e sua população são vistos por outros Estados ou pelo público estrangeiro.

Essas assertivas se diferenciam em níveis de prioridade analítica, de acordo com o tipo de megaevento esportivo considerado ou com o Estado que o sedia, ou que se candidata a sediá-lo. Contudo, em todos os casos, as evidências empíricas sobre as quais se sustentam são relativamente escassas. Quanto à primeira afirmação, a insuficiente sustentação empírica não permite assegurar a existência de uma relação de causalidade entre o esporte de alto rendimento/megaeventos e o engajamento da população com a prática esportiva ou atividade física, senão apenas que esse efeito esperado ocorre entre os indivíduos que já praticam (ou praticaram) esportes.

A segunda asserção, por sua vez, mostrou-se enganosa na maioria dos casos. Em Londres 2012, por exemplo, houve um "deslocamento" dos turistas regulares, que escolheram não visitar a cidade no período dos Jogos Olímpicos, para evitar eventuais aglomerações por conta do evento. $\mathrm{O}$ terceiro tipo de legados ainda é pouco explorado pela produção acadêmica, de modo que a análise de Chalip (2006) representa uma exceção. Não obstante, trata-se de uma temática que possui significativo potencial de desenvolvimento para novas pesquisas pois, embora possamos observar a ocorrência de um sentimento, quase religio- 
so, de harmonia coletiva em torno dos referidos eventos, pouca atenção tem sido dada à "comunidade" (Durkheim 1996) que deles resulta. A regeneração urbana é a mais visível e mensurável entre as categorias de legados. Entretanto, nem por isso é menos controversa, dado que frequentemente os projetos de regeneração em larga escala não estão em consonância com os interesses dos residentes e da comunidade local, como observado na experiência de Londres 2012 (Davis \& Thornley 2010; Raco \& Tunney 2010; Hayes \& Horne 2011; Kenelly \& Watt 2011). Finalmente, a perspectiva de fazer uso dos megaeventos esportivos para melhorar ou mesmo alterar a imagem de um país está se tornando gradualmente mais persuasiva. É notável que muitos Estados nacionais vêm instrumentalizando o esporte para promover a sua imagem ou "marca" (Van Ham 2011; Grix \& Lee 2013), na tentativa de adquirir prestígio internacional.

No que se refere à produção acadêmica brasileira, observamos que o debate sobre os megaeventos é um pouco mais recente, tendo sido impulsionada pelo ingresso do Brasil no grupo de países que foram contemplados, pelos organismos esportivos internacionais, com o direito de sediar eventos esportivos de grande magnitude. Com efeito, a realização de tais eventos em nosso país tem resultado em uma profusão de estudos nas mais diversas áreas de conhecimento, que se debruçam, entre outros tópicos, sobre os interesses subjacentes (Almeida, Mezzadri \& Marchi 2009; Resende 2010; Mascarenhas 2012; Schausteck de Almeida \& Marchi Jr. 2013; Almeida \& Marchi Jr. 2014; Bottura 2014), os fatores que convergiram para a escolha do país, a execução dos projetos de cada um dos eventos (Sánchez \& Broudehoux 2013; Figuerôa et al., 2014; Matos 2014a), e os conflitos advindos de sua realização na sociedade brasileira (Alves 2012; Braathen, Sørbøe \& Mascarenhas 2014).

No tocante à discussão sobre legados, há de se destacar, inicialmente, a elaboração de uma coletânea de textos intitulada Legados de Megaeventos Esportivos, resultante de uma parceria entre o Ministério do Esporte e o Conselho Federal de Educação Física. Trata-se de uma compilação de textos que subsidiaram o Seminário "Gestão de Legados e Megaeventos Esportivos", ocorrido no mês de maio de 2008, cujo objetivo central era o de promover o debate sobre um conjunto de pesquisas elaboradas no Brasil desde meados do ano anterior, quando se realizou na cidade do Rio de Janeiro a XV edição dos Jogos Pan-Americanos (DaCosta et al., 2008). No referido seminário foram identificados, de acordo com os editores, cinco grandes categorias de legados: os legados do evento propriamente dito; os legados gerados pela candidatura; os legados para a imagem do país; legados de governança e, por fim, legados de conhecimento. Observamos, em um breve exercício comparativo, que os três primeiros conjuntos de legados - evento, candidatura e imagem - se referem a aspectos comuns àquelas cinco categorias de legados identificadas na literatura internacional, aludidas anteriormente. As duas últimas são mais específicas do contexto local, compreendendo uma projeção de aprimoramento das instituições políticas do país, bem como de aquisição de conhecimento técnico e acadêmico relacionado com os megaeventos esportivos.

Em outra semelhança com a referida literatura, observamos também a ênfase na perspectiva de ganhos econômicos, sustentados em uma projeção de cenários futuros. Tratava-se, então, de uma iniciativa governamental e, como tal, orientava-se para sustentar a posição política do governo de investir na realização de megaeventos esportivos como uma de suas principais políticas na área esportiva. Na ocasião do seminário o Brasil já se elegera sede da Copa do Mundo de 2014 e pleiteava o direito de sediar os Jogos Olímpicos de 2016. Após confirmada a escolha do Rio de Janeiro como cidade-sede pelo Comitê Olímpico Internacional (COI), o debate sobre legados de megaeventos se difundiu, tornando-se objeto de diversos trabalhos acadêmicos (Betti 2009; 
Ouriques 2009; Proni 2009; Rubio 2009; Souza \& Marchi Jr. 2010; Domingues, Betarelli \& Magalhães 2011; Bernabé \& Starepravo 2014; Reis, Sousa-Mast \& Gurgel 2014). O presente artigo visa contribuir a essa produção, destacando a noção de "legados pré-evento" para discutir os efeitos das alterações jurídicas adotadas pelo país-sede para atender às demandas das organizações esportivas internacionais que possuem o controle sobre o esporte de alto rendimento e os eventos a ele correlatos, os quais denominamos, em caráter preliminar, de legados institucionais. Nesse sentido, o objetivo do texto é analisar os impactos que a realização da Copa do Mundo e dos Jogos Olímpicos do país vêm produzindo em suas instituições.

\section{Metodologia}

A discussão sobre os megaeventos esportivos, em geral, e seus legados, em particular, vem se desenvolvendo em diferentes áreas do conhecimento, a exemplo da Educação Física, da Administração, do Planejamento Urbano, da Ciência Política e do Direito. A despeito desse caráter multidisciplinar, entendemos que os estudos a partir dos quais cada uma dessas áreas examina a temática são municiados de dilemas e questões que são inerentes às respectivas disciplinas acadêmico-científicas, ainda que em diálogo com as demais. Assim sendo, e tendo em vista as proposições de Cortes \& Lima (2012) sobre as contribuições da Sociologia para a análise das políticas públicas, entendemos que o primeiro aspecto a enfatizar, na apresentação da estrutura metodológica de nossa análise, é que essa foi elaborada sob um ponto de vista sociológico. Nesse sentido, cumpre registrar que dois fundamentos teóricos principais balizaram o trabalho. Inicialmente, o pressuposto weberiano segundo a qual a abordagem sociológica das normas jurídicas não se limita à análise de seu conteúdo objetivo, devendo compreender, sobretudo, a conjunção de interesses e fatores históricos da qual são resultado, bem como os efeitos que produzem sobre as relações sociais (Weber 2001). Esse pressuposto nos auxilia na delimitação do recorte analítico do artigo, que se circunscreve aos efeitos que a construção de normas jurídicas excepcionais para a realização dos megaeventos esportivos no Brasil podem produzir nas instituições do país. Consoante ao primeiro, o segundo fundamento teórico adotado consiste no entendimento, proposto pela vertente sociológica do neoinstitucionalismo, de que as "instituições" não são apenas "as regras, procedimentos ou normas formais, mas também os esquemas cognitivos e os modelos morais que fornecem 'padrões de significação’ que guiam a ação humana” (Hall \& Taylor 2003, p.209).

Partindo, pois, das premissas supramencionadas, examinamos os efeitos das alterações jurídico-institucionais efetuadas pelo governo federal brasileiro visando a adquirir, e após conquistar, o direito de sediar os referidos eventos. Cabe ressaltar que, ainda que a estrutura federativa do país tenha ocasionado modificações legislativas também em esferas subnacionais de governo, essas não foram objeto da presente análise. Outra orientação metodológica que merece ser destacada diz respeito ao aspecto do fenômeno a ser aqui analisado. Isso porque as alterações legislativas levadas a efeito pelo governo federal vêm sendo abordadas por alguns dos estudos sobre os megaeventos esportivos realizados no Brasil (Oliveira 2013; Matos 2014a; 2014b). Essa abordagem tem se concentrado, sobretudo, em três elementos: $(i)$ os interesses que convergiram para a criação e/ou modificação excepcional das leis em questão; (ii) a forma como se deu o processo legislativo do qual resultaram; (iii) o seu conteúdo objetivo. Buscamos aqui enfatizar um quarto aspecto do problema, qual seja, os efeitos - no sentido que Weber (2001) atribui à leitura sociológica do direito que essas alterações legislativas vêm produzindo nas instituições nacionais. 
Isso não significa que estejamos desconsiderando os três elementos anteriores. Ao contrário, entendemos que, para discutir os efeitos que as alterações legislativas efetuadas em nome do cumprimento dos compromissos firmados com a FIFA e com o COI, torna-se necessário reconstituir o cenário no qual esses institutos jurídicos foram introduzidos, e com o qual passaram a dialogar. Desse modo, reportamos-nos àqueles três elementos na medida em que nos auxiliaram a cumprir o objetivo aqui proposto. Sendo assim, dividimos o artigo em três seções: na primeira, estabelecemos um breve retrospecto das condicionalidades que balizaram o processo de escolha da sede dos referidos eventos, bem como o papel que o governo federal brasileiro desempenhou nesse processo. Em seguida, apresentamos as alterações que foram introduzidas na legislação federal para atender às exigências da FIFA e do COI, utilizando como principais fontes de consulta, para levantamento de dados, os seguintes documentos: Lei 8.666/1993; Lei 9.279/1996; Lei 10.406/2002; Lei 10.671/2003; Lei 12.035/2009; Lei 12.462/2011; Lei 12.663/2012; Lei 12.668/2012; Lei $12.722 / 2012$ e Lei 12.745/2012. Por fim, analisamos, na última seção, alguns dos efeitos institucionais das alterações legislativas examinadas.

\section{A escolha do país/cidade-sede: condicionalidades e arranjos políticos}

Definindo as diretrizes estabelecidas pelo COI para a escolha da XXXI edição dos Jogos Olímpicos, a ser realizada em 2016, o documento 2016 Candidature Procedure and Questionnaire era constituído por três partes: (i) Candidature Procedure, que definia as regras, prazos e procedimentos que deveriam ser observados pelas concorrentes; (ii) IOC Questionnaire, que apresentava um questionário cujas respostas deveriam compor o dossiê de candidatura, com o fim de subsidiar uma avaliação técnica de cada uma das cidades-candidatas e (iii) Instructions, que fornecia orientações precisas à proposição da candidatura ao COI, indicando também os documentos complementares que deveriam ser anexados ao dossiê. Entre as três partes, aquela que fornece informações relevantes à presente análise é a segunda. Os dados requeridos pelo questionário, com vistas a comparar todas as candidaturas, eram de grande abrangência, contemplando um total de dezessete temas: 1) Visão, Legado e Comunicação; 2) Conceito Geral dos Jogos Olímpicos; 3) Clima e Estrutura Política e Econômica; 4) Aspectos Legais; 5) Formalidades Aduaneiras e de Imigração; 6) Meio Ambiente e Meteorologia; 7) Finanças; 8) Marketing; 9) Locais de Competição; 10) Jogos Paraolímpicos; 11) Vila Olímpica; 12) Serviços Médicos e Controle de Doping; 13) Segurança; 14) Acomodação;15) Transporte; 16) Tecnologia; 17) Operações de Mídia (IOC 2008).

Não pretendemos fazer uma discussão exaustiva de cada um desses temas, apenas registrar informações coletadas que entendemos contribuir com o objetivo deste artigo. Assim sendo, o que é importante salientar aqui é o papel de destaque atribuído pelo COI ao suporte governamental para respaldar a realização dos Jogos Olímpicos. Dito de outra maneira, para que os Comitês de Candidatura pudessem cumprir integralmente as garantias exigidas no caderno de encargos, era preciso estabelecer uma aliança com seus respectivos governos. Isso significa que a fiança e a participação governamentais, em maior ou menor grau, eram requisitos necessários para que a pretensão de recepcionar o referido evento pudesse ser bem-sucedida. Com efeito, a sólida articulação entre o Comitê de Candidatura do Rio de Janeiro e os governos federal, estadual e municipal foi um dos principais, senão o principal ponto de argumentação em favor da postulação carioca, sendo amplamente enfatizada no dossiê de candidatura aos Jogos de 2016. Logo na seção introdutória deste último, encontramos uma carta endereçada ao COI, assinada simultaneamente pelo Presidente da República, pelo Governador do Estado do Rio de Janeiro, pelo Prefeito da cidade do Rio de Janeiro, e pelo Presidente do Comitê Olímpico Brasileiro 
${ }^{2}$ Respectivamente: Luiz Inácio Lula da Silva, Sérgio Cabral, Eduardo Paes e Carlos Arthur Nuzman.
$(\mathrm{COB})^{2}$, que reiterava essa aliança e, entre outras, apresentava as seguintes declarações:

Essa carta reafirma o apoio total e firme do Governo do Brasil, do Estado do Rio de Janeiro e da cidade do Rio de Janeiro, junto com o Comitê Olímpico Brasileiro, à candidatura do Rio para sediar os Jogos Olímpicos e Paraolímpicos de 2016. [...]. Já esboçamos todas as novas estruturas legais necessárias para os Jogos [...]. De modo a complementar uma abrangente legislação existente para a execução dos Jogos, Decretos Municipais, Estaduais e Federais irão fornecer as capacidades legais para que o Governo, a APO e o Comitê Organizador possam assumir todas as responsabilidades relacionadas aos Jogos. Temos firmado nosso apoio e demonstrado nosso engajamento a assegurar que todas as garantias e exigências do COI e do IPC sejam cumpridas. Governo e esporte estão unidos em apoio a essa candidatura histórica (COB 2009, pp.11-12; sem grifos no original)

Essas afirmações denotam o grande envolvimento do governo brasileiro com a candidatura do Rio de Janeiro, que se tornou, como dito, fator decisivo para que essa se tornasse bem-sucedida. Para uma compreensão dos efeitos práticos desse apoio governamental, é interessante observar que a postulação para sediar os Jogos Olímpicos de 2016 foi apenas a terceira tentativa da cidade para receber esse que é considerado um dos dois eventos esportivos de maior magnitude na atualidade. A primeira delas se deu no início da década de 1990, quando o objetivo de se candidatar à sede da XXVIII edição dos Jogos, em 2004, foi incluído no Planejamento Estratégico da Cidade do Rio de Janeiro, elaborado no primeiro mandato de César Maia como prefeito da cidade. O escopo central desse planejamento era incluir o município carioca no circuito das cidades globalizadas, tendo como horizonte de ação o modelo de regeneração urbana experimentado por Barcelona, que se consagrou com a recepção dos Jogos Olímpicos de 1992. O principal contributo de tal experiência se inseriu no processo de elaboração do referido instrumento de planejamento por meio da contratação, pela administração pública municipal do Rio de Janeiro, de consultores que estiveram à frente da reestruturação urbana da cidade catalã (Benedicto 2008; Cruz 2010; Miagusko 2012; Oliveira 2012; Braathen, Sørbøe \& Mascarenhas 2014). A candidatura para os Jogos Olímpicos de 2004 foi, portanto, erigida a partir de dois objetivos principais: (i) a perspectiva de consolidar o Rio de Janeiro como polo de atração internacional, com vistas a impulsionar seu desenvolvimento econômico e cultural nos moldes das chamadas cidades globais; (ii) a projeção de catalisar as transformações urbanísticas delineadas pelo modelo de planejamento urbano adotado, inspirado no exemplo de Barcelona. Contudo, em que pese o apoio popular amealhado por essa candidatura, conforme assinalado por Miagusko (2012), os esforços se revelaram frustrados, dado que a cidade foi eliminada ainda na primeira fase do processo de seleção da sede dos Jogos Olímpicos de 2004, que chegaria a termo com a escolha da cidade de Atenas, na Grécia, para recepcionar essa edição do evento (Benedicto 2008; Oliveira 2012).

O insucesso dessa tentativa, contudo, não arrefeceu os ânimos da coalizão de interesses que se formara com vistas à realização do projeto olímpico carioca. Alguns eventos subsequentes e a incorporação de novos atores convergiram para a permanência e aprimoramento de tal projeto. Dentre os eventos, dois merecem destaque. O primeiro foi a realização, no Rio de Janeiro, da XV edição dos Jogos Pan-Americanos, em 2007. De fato, a convite do COB, a cidade postulou (e conquistou) o direito de sediar esse evento esportivo regional, com o intuito de que sua organização pudesse credenciá-la em uma futura candidatura olímpica. De acordo com Black (2007), trata-se de uma estratégia utilizada mundialmente: diferentes Estados organizam os chamados "Jogos de Segunda Ordem" para provar que estão aptos ao desafio logístico de sediar um evento esportivo de maior grandeza. Além da visibilidade e da 
oportunidade de demonstrar a "eficiência" dos organizadores, projetava-se, ainda, que a infraestrutura demandada pelos Jogos Pan-Americanos de 2007 pudesse ser construída sob os padrões do COI, de forma a antecipar a construção e/ou reforma de praças e equipamentos esportivos necessários à recepção dos Jogos Olímpicos. A perspectiva subjacente a tal projeto era de que, ao erigir essa estrutura mesmo antes da abertura do processo de escolha, o Rio de Janeiro se antecipasse aos eventuais concorrentes e às próprias exigências do COI, o que poderia lhe conferir uma vantagem comparativa em uma nova candidatura, que viria a ocorrer em 2003, quando a cidade se apresentou como aspirante à realização dos Jogos Olímpicos de 2012 (Benedicto 2008; Cruz 2010; Miagusko 2012).

Não obstante, essa segunda candidatura também se revelou frustrada, sendo eliminada na primeira etapa do processo de escolha da sede dos Jogos Olímpicos de 2012, ao termo do qual Londres seria eleita para recepcionar a XXX edição do evento. A despeito do segundo resultado negativo, o projeto olímpico carioca manteve-se firme em seus propósitos. Nesse sentido, a execução dos Jogos Pan-Americanos de 2007 se divorciou, progressivamente, da proposta original, constante do dossiê de candidatura apresentado à Organização Desportiva Pan-Americana (ODEPA), aproximando-se, de modo gradual, de uma formatação olímpica. O intuito dos organizadores, aqui, era "vender" a organização desse evento regional como um estágio de aprendizado para que a cidade se credenciasse em mais uma tentativa de sediar os Jogos Olímpicos, o que de fato ocorreu, como pode ser verificado pela inserção, na carta que constava do dossiê de candidatura para a recepção da edição de 2016, a que nos referimos anteriormente, da seguinte afirmação: "aprendemos muito com a realização bem-sucedida dos Jogos Pan-americanos e Parapan-americanos Rio 2007. E nos beneficiamos do legado físico desses Jogos, infraestrutura e novas instalações do evento" (COB 2009). O segundo evento que entendemos necessário destacar foi a escolha, anunciada em 30 de outubro de 2007, do Brasil para sediar a Copa do Mundo de Futebol de 2014. Tal evento foi também mobilizado em favor da postulação aos Jogos Olímpicos de 2016, especialmente porque permitiu ao Comitê de Candidatura argumentar que a infraestrutura construída pelo governo para a primeira restaria como legado físico a ser aproveitado pelo segundo evento. E esse seria beneficiário não apenas da estrutura material legada pela Copa do Mundo, mas também da própria política do governo brasileiro, cujo escopo era o de conferir amplo suporte à realização de megaeventos esportivos no país, o que nos leva ao segundo elemento para que o projeto olímpico da cidade do Rio de Janeiro se tornasse, finalmente, bemsucedido: a incorporação gradual de novos atores, com destaque para o governo federal.

Para que possamos melhor compreender o impulso que a aproximação do governo federal conferiu à candidatura olímpica carioca, cumpre estabelecer algumas considerações sobre as constelações de atores que, usualmente, conferem sustentação a um projeto dessa natureza. A esse respeito, cabe inicialmente considerar que, nos últimos anos, a busca pelo direito de sediar um megaevento esportivo tem se configurado, ao menos discursivamente, como uma estratégia de ação para o desenvolvimento econômico. Ademais, dada sua robusta conexão "com a realização de grandes projetos de infraestrutura, de instalações e de renovação urbana, essa categoria de megaeventos tem demonstrado também um grande poder de reestruturação territorial das cidades anfitriãs" (Oliveira 2012, p.157), o que tende a corroborar com a mencionada configuração. Assim sendo, a realização de um evento de tal natureza envolve diferentes interesses, que transcendem a esfera meramente esportiva, aproximando da perspectiva de sua realização atores tais como gestores públicos e empresas de diferentes segmentos da atividade econômica. Trata-se, no entanto, de um processo dinâmico, 
de sorte que alguns personagens que desempenham papeis relevantes em um dado momento podem desaparecer, ou ver sua importância diminuída, ao passo que outros se incorporam, tornando-se mesmo decisivos, ao longo do processo (Oliveira 2012).

No caso do projeto olímpico do Rio de Janeiro, é mister reconhecer que, de início, tratava-se de uma iniciativa, sobretudo, da Prefeitura Municipal - que, naquele momento, assumia um protagonismo até mais significativo do que aquele desempenhado pelo $\mathrm{COB}$ - que apoiou-se, de um lado, em uma aliança com setores do empresariado da cidade e, de outro, com consultores internacionais que estiveram envolvidos no processo de reestruturação urbana da cidade de Barcelona. Vimos que, mesmo com o insucesso dessa tentativa, o projeto se manteve, incorporando novos atores nas coalizões de interesses que construíram, respectivamente, as segunda e terceira candidaturas (Benedicto 2008; Miagusko 2012; Oliveira 2012).

Permanece indubitável, contudo, que, entre esses novos atores, foram os agentes e instituições do governo federal que desempenharam o papel mais relevante e decisivo para a escolha do Rio de Janeiro como sede dos Jogos Olímpicos de 2016. Tal assertiva pode ser sustentada, inicialmente, porque muitas das garantias exigidas no caderno de encargos do COI se constituem, no Brasil, como matéria de competência legislativa desse nível de governo.

De fato, do total de 46 garantias governamentais apresentadas pelo Comitê da Candidatura Rio 2016, 34 eram compartilhadas pelos três níveis de governo, três competiam ao município e/ou ao estado do Rio de Janeiro e nove eram exclusivamente asseguradas pelo governo federal. Essas últimas eram as seguintes: ( $i$ ) o aumento da capacidade e a renovação do Aeroporto Internacional do Rio de Janeiro; ( $i i)$ o financiamento, através da Caixa Econômica Federal, da Vila Olímpica e Paraolímpica e das Vilas de Legado; (iii) a instituição de um sistema classificatório dos hotéis, a ser aprovado pelo Ministério do Turismo; (iv) a isenção de vistos para o ingresso de estrangeiros no país; $(v)$ a rapidez na concessão de vistos de trabalho para os trabalhadores temporários dos Jogos, com isenção de taxas e impostos; (vi) a autorização para entrada, utilização e saída de produtos especializados para a realização do evento, incluindo armas de fogo e munição, equipamentos audiovisuais, entre outros; (vii) a aplicação do regulamento antidoping do COI e da Agência Mundial Antidoping de 2016; (viii) a provisão de acesso às frequências de radiodifusão demandadas pela organização dos Jogos Olímpicos; (ix) a isenção financeira para uso das frequências de radiodifusão distribuídas durante os Jogos.

Em segundo lugar, porque coube ao governo federal afiançar a realização dos Jogos Olímpicos no Brasil, inclusive em caso de um eventual déficit orçamentário do Comitê Organizador (Brasil 2009). Ainda que o dossiê da candidatura carioca tenha afirmado o compartilhamento dessa garantia entre os três entes governamentais, é preciso registrar que a participação do governo federal na provisão de recursos financeiros foi muito maior e, portanto, mais decisiva. Isso porque, dada a estrutura federativa em que se erige o sistema tributário e a organização das finanças públicas no país (Rezende 1995; Bachur 2005; Brasil 2011), o município e o estado do Rio de Janeiro não teriam condições de, isoladamente ou em associação, prover as garantias financeiras exigidas pelo COI. Assim sendo, é lícito considerar que a incorporação do governo federal à linha de frente da candidatura olímpica do Rio de Janeiro foi fundamental para que essa se tornasse, pela primeira vez, vitoriosa. Cabe observar que, de um modo ou de outro, o governo federal também apoiara as candidaturas anteriores. Todavia, na candidatura para os Jogos de 2016 o envolvimento se deu de modo mais orgânico e contundente - tanto no aporte de recursos financeiros, advindos do orçamento público federal, quanto no 
empenho do carisma político do então chefe do poder Executivo, Luis Inácio Lula da Silva, para o fortalecimento da construção simbólica sobre a qual se erigiu tal candidatura (Oliveira 2012) -, contribuindo significativamente para que o Rio de Janeiro fosse eleito, no ano de 2009, a cidade-sede dos Jogos Olímpicos de 2016.

IV. Das medidas para a realização da Copa do Mundo de 2014 e dos Jogos Olímpicos de 2016 no Brasil: alterações legislativas efetuadas pelo governo federal brasileiro

Entre as medidas governamentais que vêm sendo adotadas com vistas à realização da Copa de 2014 e dos Jogos Olímpicos de 2016 nos ocuparemos, como dito, daquelas que, efetuadas pelo governo federal, promoveram alterações legislativas a fim de adequar a estrutura jurídico-institucional do país às demandas impetradas pela FIFA e pelo COI e, assim, prover as condições para que os compromissos assumidos pelas respectivas candidaturas pudessem ser cumpridos. Para tanto, utilizaremos como fonte de consulta, para levantamento de dados, os seguintes documentos: ( i) Lei 12.035, de $1^{\circ}$ de outubro de 2009; (ii) Lei 12.663, de 5 de junho de 2012 e (iii) Lei 12.462, de 4 de agosto de 2011.

A primeira foi instituída com "a finalidade de assegurar garantias à candidatura da cidade do Rio de Janeiro a sede dos Jogos Olímpicos e Paraolímpicos de 2016 e de estabelecer regras especiais para a sua realização" (Brasil 2009). Sendo sancionada no dia $1^{\circ}$ de outubro de 2009, essa lei teve sua aplicação condicionada à vitória da postulação carioca no processo de escolha levado a efeito pelo COI para a definição da cidade que recepcionaria os Jogos de 2016, que chegaria a termo no dia seguinte à sua sanção. Tal diploma legislativo, portanto, visava a prover condições jurídico-institucionais excepcionais para que a candidatura Rio 2016 saísse vitoriosa no referido processo. Confirmada essa possibilidade, seus dispositivos entrariam em vigor, mas em caráter transitório, haja vista que o prazo de vigência se iniciaria em 2 de outubro de 2009 e se encerraria em 31 de dezembro de 2016, quando deixaria de produzir efeitos, conforme previsão contida em seu texto. Composta por 16 artigos, a Lei 12.035/2009, também chamada de Ato Olímpico, introduzia e/ou alterava normas legislativas referentes às seguintes matérias: (a) imigração; (b) propriedade industrial e intelectual; (c) contratos prévios de concessão pública; (d) doping; (e) gratuidade de serviços públicos; (f) legislação complementar; (g) garantias financeiras. Quanto à imigração, flexibilizou a Lei n 6.815 , de 19 de agosto de 1980, que regulamenta o ingresso de estrangeiros em território brasileiro, ao dispensar aqueles que venham ao Brasil em virtude dos Jogos de 2016 da exigência de obtenção do visto de entrada no país. Para tanto, reputou suficiente a apresentação de passaporte válido, acompanhado de documento expedido pelo COI que comprovasse o envolvimento com o evento em questão.

No que diz respeito à propriedade industrial e intelectual, atribuiu ao governo federal a obrigatoriedade de controlar, fiscalizar e reprimir quaisquer atos que infringissem os direitos de exploração comercial dos símbolos, expressões idiomáticas e produtos associados aos Jogos. No tocante aos contratos prévios de concessão pública, autorizou a administração pública federal a rompê-los unilateralmente, se de interesse fosse do Comitê Organizador dos Jogos Olímpicos. Isso incluía a concessão de espaços publicitários nos aeroportos e demais áreas convenientes ao COI e seus parceiros comerciais. A lei previa, ainda, a inclusão de uma ressalva nos contratos futuros de concessão pública, com o mesmo fim. Outro dispositivo do Ato Olímpico estabelecia a necessidade de observância das regras da Agência Mundial Antidoping, COI e CPI, garantindo sua prevalência em caso de conflito com a legislação nacional. Ademais, assegurava a provisão gratuita, ao Comitê Organizador dos Jogos, de serviços públicos tais como saúde, segurança, vigilância sanitária, alfândega e 
de frequência de radiodifusão. Para além dessas garantias expressas em seu texto, a Lei 12.035/2009 previu, ainda, a edição, pelo governo brasileiro, de "normas complementares que se façam necessárias para a realização dos Jogos Rio 2016" e o suporte, com recursos públicos, de "eventuais défices operacionais do Comitê Organizador [...] a partir da data de sua criação" (Brasil 2009).

A segunda fonte consultada, Lei 12.663/2012, estabeleceu, entre outras, regras especiais para a realização da Copa das Confederações FIFA 2013 e a Copa do Mundo FIFA 2014. Diferente do Ato Olímpico, essa, que ficou conhecida como Lei Geral da Copa, foi sancionada após a escolha do Brasil como país-sede dos eventos da FIFA, dispondo sobre as seguintes matérias: (a) propriedade industrial e direitos comerciais; (b) responsabilidade civil; (c) venda de ingressos; (d) locais de competições; (e) excepcionalidades diversas; (f) gratuidade de serviços públicos; (g) regulamentação complementar. Os dispositivos que tratam dos direitos comerciais e a propriedade industrial associados à Copa do Mundo alteraram o quadro normativo estabelecido pela Lei 9.279, de 14 de maio de 1996, que regulamenta o registro e a propriedade de marcas e patentes industriais, determinando, no inciso XIII do seu artigo 124, que não podem ser registrados como marca "nome, prêmio ou símbolo de evento esportivo, artístico, cultural, social, político, econômico ou técnico, [...]" (Brasil 1996; sem grifos no original). Suspendendo a aplicabilidade dessa norma para os eventos da FIFA, a Lei Geral da Copa estabeleceu, em seu artigo $3^{\circ}$, que:

O Instituto Nacional da Propriedade Industrial (INPI) promoverá a anotação em seus cadastros de alto renome das marcas que consistam nos seguintes Símbolos Oficiais de titularidade da FIFA, nos termos e para os fins da proteção especial de que trata o art. 125 da Lei n ${ }^{\circ} 9.279$, de 14 de maio de 1996: I - emblema FIFA; II - emblemas da Copa das Confederações FIFA 2013 e da Copa do Mundo FIFA 2014; III - mascotes oficiais da Copa das Confederações FIFA 2013 e da Copa do Mundo FIFA 2014; e IV - outros Símbolos Oficiais de titularidade da FIFA, indicados pela referida entidade em lista a ser protocolada no INPI, que poderá ser atualizada a qualquer tempo; Parágrafo único. Não se aplica a proteção prevista nesse artigo a vedação de que trata o inciso XIII do art. 124 da Lei $n^{o}$ 9.279, de 14 de maio de 1996. Art. $4^{\circ} \mathrm{O}$ INPI promoverá a anotação em seus cadastros das marcas notoriamente conhecidas de titularidade da FIFA, nos termos e para os fins da proteção especial de que trata o art. 126 da Lei n ${ }^{\circ} 9.279$, de 14 de maio de 1996, conforme lista fornecida e atualizada pela FIFA. Parágrafo único - Não se aplica à proteção prevista nesse artigo a vedação de que trata o inciso XIII do art. 124 da Lei $n^{\circ}$ 9.279, de 14 de maio de 1996 (Brasil 2012a; sem grifos no original).

Além de suspender os efeitos do inciso XIII do artigo 124 da Lei 9.279/96 e, por conseguinte, permitir o registro de marcas e símbolos dos eventos FIFA no Brasil, a Lei Geral da Copa tipificou criminalmente a reprodução, a imitação e a falsificação indevidas, assim como a importação, exportação, venda, distribuição e oferta de quaisquer símbolos associados aos eventos mencionados. Do mesmo modo, tornou crime a associação de produtos e serviços com a entidade, a Copa das Confederações 2013 ou a Copa do Mundo de 2014, para fins publicitários, sem a devida autorização da FIFA.

Quanto à responsabilidade civil, a Lei Geral da Copa promoveu, ainda que indiretamente, o afastamento de alguns dispositivos da Lei 8.078, de 11 de setembro de 1990, que instituiu diretrizes legais para a proteção do consumidor, bem como da Lei 10.406, de 10 de janeiro de 2002, que estabeleceu a versão atual do Código Civil Brasileiro. A primeira determina, entre os artigos 12 e 17, a responsabilidade de fornecedores de produtos e serviços em indenizar, independentemente de culpa, eventuais prejuízos que esses tenham gerado aos seus respectivos consumidores. Por seu turno, o Código Civil dispõe, em seu artigo 
927, que a pessoa que prejudica outra em virtude de ato ilícito tem a obrigação civil de reparar o prejuízo, desde que reste comprovada a culpa pelo dano causado. Não obstante, em seu artigo 931, o mesmo diploma legal assinala que "os empresários individuais e as empresas respondem independentemente de culpa pelos danos causados pelos produtos postos em circulação" (Brasil 2002a; sem grifos no original). Tal normativa decorre de um suposto, presente na doutrina jurídica, de que quaisquer atividades econômicas envolvem algum tipo de risco que é implicitamente assumido pelos agentes que propõem a desenvolvê-las, com a expectativa de obter lucro. Disso resulta a chamada responsabilidade civil objetiva, que consiste na obrigação de reparar eventuais danos causados pela atividade empresarial, independentemente da culpa por sua ocorrência. Embora a Copa do Mundo seja um evento comercial, objeto de exploração econômica pela FIFA e seus parceiros, o governo neutralizou, por meio do artigo 23 da Lei Geral da Copa, os riscos correlatos à sua comercialização.

A Lei Geral da Copa promoveu alterações também na Lei 10.671, de 15 de maio de 2003, que instituiu o Estatuto do Torcedor, que dispõe sobre os direitos e garantias para o consumidor esportivo. A esse respeito, um primeiro aspecto a observar é que, se em relação à propriedade industrial e à responsabilidade civil os esforços de modificação se concentraram sobre as normativas que regulamentam a atividade econômica, com relação ao Estatuto as alterações se dirigiram às diretrizes legais que regulamentam a realização de eventos esportivos no país, a fim de moldá-las aos padrões de organização e exploração econômica concebidos pela FIFA. Nesse sentido, as mudanças principais se deram em relação ao artigo 13-A do Estatuto, que determina nove condições para acesso e permanência nas praças esportivas pelos torcedores, indicadas abaixo:

I - estar na posse de ingresso válido; II - não portar objetos, bebidas ou substâncias proibidas ou suscetiveis de gerar ou possibilitar a prática de atos de violência; III - consentir com a revista pessoal de prevenção e segurança; IV não portar ou ostentar cartazes, bandeiras, símbolos ou outros sinais com mensagens ofensivas, inclusive de caráter racista ou xenófobo; $\mathrm{V}$ - não entoar cânticos discriminatórios, racistas ou xenófobos; VI - não arremessar objetos, de qualquer natureza, no interior do recinto esportivo; VII - não portar ou utilizar fogos de artifício ou quaisquer engenhos pirotécnicos ou produtores de efeitos análogos; VIII - não incitar e não praticar atos de violência no estádio, qualquer que seja a sua natureza; e IX - não invadir e não incitar a invasão, de qualquer forma, da área restrita aos competidores (Brasil 2003; sem grifos no original).

Destacamos o inciso II porque este regula dois aspectos de interesse direto da FIFA, o que demandou, diante das tratativas do governo federal e demais atores envolvidos, a adequação desse dispositivo. O primeiro consiste no porte de objetos que possam se transmutar em instrumentos para praticar atos de violência. Embora bastante genérica, tal restrição atingiu principalmente o porte de mastros de bandeiras, instrumentos musicais e fogos de artifício, comumente utilizados pelos torcedores antes da Lei 10.671/2003.

O segundo aspecto, mais relevante, diz respeito à entrada nas praças esportivas de posse de bebidas de teor alcoólico. O suposto lógico dessa proibição é que o Estatuto do Torcedor vetou, ainda que não expressamente, a venda de bebida alcoólica em estádios, ginásios e outros locais de competição esportiva. Essa é uma questão sensível à FIFA, dado que a comercialização de produtos dessa natureza é uma significativa fonte de receitas para os organizadores de eventos esportivos. Há que se notar também que, entre os principais patrocinadores da entidade, bem como do próprio evento, encontra-se uma empresa de cerveja, à qual interessa utilizar a Copa do Mundo para promover a sua marca. A Lei Geral da Copa resolveu a primeira questão por meio de seu artigo 
50, que acrescentou um inciso ao artigo 13-A do Estatuto do Torcedor, acima citado, que acrescentou a seguinte condição de acesso e permanência aos locais de competição: "X - não utilizar bandeiras, inclusive com mastro de bambu ou similares, para outros fins que não o da manifestação festiva e amigável" (Brasil 2012a; sem grifos no original). Trata-se de evidente recurso de neutralização do inciso II do mesmo artigo que, contudo, não foi extinto. Cumpre ressaltar que essa alteração legislativa não é provisória, de modo que a produção de efeitos do novo dispositivo alcança também o período posterior à realização da Copa do Mundo de 2014.

A segunda questão é resolvida pelo artigo 68 da Lei Geral da Copa, ao determinar que as normas do Estatuto do Torcedor seriam aplicadas no que coubessem à realização da Copa das Confederações e da Copa do Mundo no Brasil, ressalvadas algumas exceções, entre as quais se encontrava o artigo 13-A. Como resultado, a norma legal que impede, ainda que indiretamente, a venda de bebidas alcóolicas em eventos esportivos realizados no país também foi suspensa pelo governo federal brasileiro. Igualmente, foram suspensos os efeitos de outras normativas presentes no Estatuto do Torcedor. Para uma compreensão adequada dessa suspensão, cabe relembrar, aqui, a estrutura da Lei 10.671/2003, cujo texto se encontra dividido em 12 capítulos: I. Disposições Gerais (artigos $1^{\circ}$ a $4^{\circ}$ ); II. Da Transparência da Organização $\left(5^{\circ}\right.$ a $\left.8^{\circ}\right)$; III. Do Regulamento da Competição (9ª 12); IV. Da Segurança do Torcedor Partícipe do Evento Esportivo (13 a 19); V. Dos Ingressos (20 a 25); VI. Do Transporte (26 e 27); VII. Da Alimentação e da Higiene (28 e 29); VIII. Da Relação com a Arbitragem Esportiva (30 a 32); IX. Da Relação com a Entidade de Prática Desportiva (33); X. Da Relação com a Justiça Desportiva (34 a 36); XI. Das Penalidades (37 a 41-A); XI-A. Dos Crimes (41-B a 41-G) e XII. Disposições Finais e Transitórias (42 a 45).

Os capítulos II, III, VIII, IX e X foram integralmente afastados pela Lei Geral da Copa. Entre os demais, constatamos o afastamento dos seguintes dispositivos: ( $i$ ) capítulo IV - artigos13-A a 17 e artigo 19, que atribuem a responsabilidade pela segurança de eventos esportivos às entidades que os organizam, estabelecem alguns deveres no tocante à estrutura para pronto atendimento de eventualidades médicas bem como a responsabilidade civil das entidades organizadoras dos eventos esportivos, independente de culpa, "pelos prejuízos causados a torcedor que decorram de falhas de segurança nos estádios ou da inobservância do disposto nesse capítulo" (Brasil 2003); (ii) capítulo V artigos 22 e 24, que regulamentam os direitos do torcedor no que diz respeito, respectivamente, à numeração do assento adquirido por meio do ingresso que comprou e à equidade de preços dos ingressos de um mesmo setor do estádio; (iii) capítulo VI - artigo 27, que exige da entidade organizadora a provisão de serviços de estacionamento para os torcedores, além de transporte de idosos, crianças e deficientes físicos; $(i v)$ capítulo VII $-\S 2^{\circ}$ do artigo 28 , que veta a cobrança de preços excessivos na venda de produtos alimentícios no interior dos locais de competição; ( v) capítulo XI - artigo 37, que cria as sanções em que as entidades organizadoras podem incorrer em caso de inobservância das normas do Estatuto do Torcedor.

Em caráter complementar, a Lei Geral da Copa definiu regras específicas para a venda de ingressos e para as condições de acesso e permanência nos locais oficiais de competição. Cabe salientar, entretanto, que em relação a essas últimas a legislação criada excepcionalmente para reger a Copa das Confederações de 2013 e a Copa do Mundo de 2014 reproduziu parte significativa do artigo 13-A do Estatuto do Torcedor. Omitiu apenas o dispositivo que impedia, indiretamente, a venda de bebidas alcoólicas no interior das praças esportivas. Assim como o Ato Olímpico, a Lei Geral da Copa assegurou ao Comitê Organizador dos eventos da FIFA no Brasil a utilização gratuita de serviços 
públicos, tais como saúde, segurança, vigilância sanitária e aduana. Diferente do primeiro, contudo, a segunda concedeu, em seu artigo 53, isenção do pagamento de despesas de natureza judiciária. Ademais, observamos a inclusão de três artigos que visam a constituir subsídio adicional para o atendimento dos desafios logísticos da organização da Copa do Mundo, particularmente em face do déficit de infraestrutura e de mobilidade urbana em relação à demanda gerada pela realização dos referidos eventos. Desse modo, o artigo 56 da Lei Geral da Copa autorizou o governo federal a decretar feriado nacional em dias de jogos da seleção brasileira de futebol, assim como conferiu aos governos estaduais e municipais a prerrogativa de instituir feriado nos dias em que fossem realizadas partidas das competições em seus respectivos territórios. Os artigos 61 e 62 autorizaram a utilização de aeródromos militares, especialmente aqueles localizados nos municípios limítrofes às cidades-sede, para embarque e desembarque tanto de passageiros quanto de carga. $\mathrm{O}$ artigo 64, por sua vez, estabeleceu que as instituições que integram o sistema nacional de educação deveriam ajustar seus respectivos calendários letivos, de modo a que as férias escolares de inverno coincidissem, obrigatoriamente, com o período de realização da Copa do Mundo no país. Finalmente, a Lei Geral da Copa dispôs que as leis brasileiras que regulam os direitos e obrigações referentes $(i)$ à propriedade industrial (Lei 9.279/1996); (ii) à propriedade intelectual de programas de computador (Lei 9.609/1998); (iii) aos direitos autorais (Lei 9.610/1998); (iv) aos direitos do torcedor (Lei 10.671/2003) seriam aplicadas subsidiariamente aos eventos FIFA no Brasil. Por "subsidiariamente" é possível entender: desde que não colidissem com as disposições da Lei Geral da Copa.

O terceiro documento que utilizamos como fonte de consulta foi a Lei 12.462, de 4 de agosto de 2011. Entre outras providências, essa lei instituiu o denominado Regime Diferenciado de Contratações Públicas (RDC). Antes de examinarmos as alterações legislativas promovidas pela lei do RDC, contudo, cabe registrar que essa não era propriamente uma condição nem da FIFA nem do COI para que seus respectivos eventos se realizassem no Brasil. Não obstante, sua elaboração se sustentou no argumento segundo o qual se fazia necessário imprimir padrões de excelência à administração pública para responder aos desafios logísticos e operacionais que a organização dos megaeventos esportivos impunha ao país. Dessa forma, o RDC foi criado para a contratação de obras, produtos e serviços necessários à realização da Copa das Confederações 2013, da Copa do Mundo de 2014, dos Jogos Olímpicos e Paraolímpicos de 2016 e das obras de infraestrutura aeroportuária para as localidades que distassem até 350 quilômetros das cidades-sede de cada um desses eventos.

Em consonância com a Lei 12.462/2011, a opção da administração pública pelo RDC deve constar do edital de abertura da licitação, resultando, quando efetuada, no afastamento das normas da Lei 8.666, de 21 de julho de 1993, que regulamentou a licitação pública no país, em harmonia com os princípios da Constituição Federal em vigor. Sob um ponto de vista administrativo, isso significou a criação de uma nova modalidade licitatória, que se somou às outras seis em vigência no país ${ }^{3}$. Mesmo preservando os princípios constitucionais que guiaram a instituição da Lei 8.666/93, a lei do RDC introduziu uma série de inovações no processo de contratação de bens e serviços pelo Estado, entre as quais cabe destacar: ( $i$ ) a criação de remuneração variável para a empresa contratada, condicionada ao desempenho desta no cumprimento do contrato; (ii) autorização para que a administração indique a marca e o modelo do objeto a ser licitado, o que era expressamente vetado pela Lei 8.666/93; (iii) a divulgação do orçamento estimado apenas no ato de encerramento do processo licitatório, em oposição à obrigatoriedade de sua divulgação no edital de

3 A Lei 8.666/93 criou as seguintes modalidades de licitação: (a) concorrência; (b) tomada de preços; (c) convite; (d) concurso; (e) leilão. A Lei 10.520, de 17 de julho de 2002 instituiu mais uma, o pregão. (Brasil 1993; 2002b). 
abertura, conforme estabelecido na legislação anterior (Oliveira \& Freitas 2011; Andrade 2012; Cardoso 2012; Sá 2012).

Essa última foi objeto de grande controvérsia, uma vez que diminuiu, ainda que transitoriamente, a transparência do processo de licitação. O governo brasileiro defendeu sua adoção argumentando que esse recurso propiciaria um estímulo à redução de preços pelos licitantes, dado que esses não teriam conhecimento do preço máximo que a administração pública aceitaria pagar pelo objeto licitado. Sustentou, ainda, que a medida evitaria a atuação cartelizada de empresas concorrentes, já que estas não teriam um parâmetro para combinar preços e, por conseguinte, direcionar o resultado da licitação. Desse modo, o sigilo sobre o orçamento estimado até o encerramento do processo representaria uma economia de recursos públicos, favorecendo o poder público e, consequentemente, a sociedade. Por outro lado, os críticos de tal medida assinalavam que a falta de publicidade criaria um ambiente de instabilidade, abrindo espaço para a prática de corrupção de agentes públicos, com vistas à aquisição de informações privilegiadas por um ou mais licitantes, em detrimento dos demais, comprometendo o princípio constitucional da isonomia. Sendo assim, a perspectiva de economia dos recursos públicos por meio dessa alteração legislativa, propalada pelo governo, seria inócua e, portanto, não poderia justificar o dispositivo legal que a instituíra (Cardoso 2012). Entendemos que, para os fins do presente trabalho, não nos cabe tomar partido nessa controvérsia. Interessa-nos, sim, identificar em que medida o RDC, criado excepcionalmente para ser aplicado às contratações de produtos e serviços vinculados à realização de megaeventos esportivos no país, vem se enraizando no ordenamento jurídico brasileiro, concorrendo para a consolidação do que vimos denominando legados institucionais, conforme discutido na próxima seção.

\section{Efeitos institucionais da realização dos megaeventos esportivos no Brasil: legados em curso}

${ }^{4}$ De acordo com Oliveira (2012), tal derivação foi efetuada pelo Professor Carlos
As alterações promovidas no ordenamento jurídico brasileiro em virtude da realização de megaeventos esportivos têm sido predominantemente discutidas a partir de um arcabouço teórico que se fundamenta no constructo teórico de "Estado de exceção", do filósofo italiano Giorgio Agamben (Vainer 2011; Alves 2012; Oliveira 2012; Rodrigues 2013; Braathen, Sørbøe \& Mascarenhas 2014; Romera 2014). Trata-se de um conceito que pretende definir a forma contemporânea do Estado de Direito moderno, que teria suplantado, de fato, a tripartição de poderes em que esse se fundou. Agamben (2004) sustenta que, se na moderna divisão tripartite de poder o Estado de exceção era uma figura jurídica de caráter restrito, que conferia ao poder Executivo a prerrogativa de pôr o ordenamento jurídico em suspensão em situações extraordinárias, como em caso de guerra ou grave crise econômica, em sua forma contemporânea essa figura jurídica não apenas transcendeu os limites que lhe cercavam originalmente, como ainda se transformou em paradigma de governo, trazendo como mais significativa consequência um profundo desequilíbrio na balança em que se sustentam os três poderes do Estado que representaria, em última instância, uma ruptura com a ordem tripartite que caracteriza os regimes democráticos do Ocidente e o consequente estabelecimento de uma nova ordem jurídico-social. Esse conceito se constituiu como uma referência para as análises sobre as modificações jurídicas e institucionais promovidas em função da organização dos megaeventos esportivos desde que dele foi derivado a noção de "cidade de exceção", utilizada, genericamente, pela literatura acadêmica nacional, para se referir "aos atos autoritários relacionados à preparação para os megaeventos esportivos do Rio de Janeiro" (Oliveira 2012, p.210). 
Vainer, que a apresentou, inicialmente, em uma palestra que proferiu no Fórum Social Urbano que se realizou no Rio de Janeiro, em 25 de março de 2010, retornando ao tema na Conferência Internacional: os megaeventos e as Cidades, realizada, ainda naquele ano, na Universidade Federal Fluminense.
Os estudos que lançam mão da noção de "cidade de exceção", derivado do conceito de "Estado de exceção" formulado por Agamben (2004), vêm se ocupando, fundamentalmente, do conteúdo objetivo das normas excepcionais criadas bem como da conjunção de fatores que convergiram para a sua criação. O objetivo deste trabalho, contudo, reside na análise dos efeitos que tais alterações legislativas vêm produzindo, ou tendem a produzir, nas relações sociais (Weber 2001). E para a delimitação do alcance de tais efeitos, aos quais denominamos "legados institucionais", tomamos como premissa a concepção, proveniente do neoinstitucionalismo sociológico, de que o conceito de instituição não diz respeito somente ao conjunto de regulamentos formais, mas também se refere aos sistemas simbólicos que, provendo modelos cognitivos de significação, também orientam a ação dos indivíduos no interior das organizações sociais, de forma que se observa uma influência mútua entre, de um lado, a racionalidade legal e, de outro, as práticas culturais. Nesse caso, temos que a racionalidade legal é também uma construção cultural e, sendo assim, a análise do aparato legislativo demanda, sob essa perspectiva, a suplantação da oposição dicotômica entre as instituições e a cultura ou, dizendo de outro modo, entre as “explicações institucionais" e as "explicações culturais" (Hall \& Taylor 2003). Trata-se de pressupostos distintos daqueles que se encontram subjacentes aos estudos sobre as alterações legislativas efetivadas em virtude dos megaeventos esportivos que se sustentam em Agamben (2004), que se orientam, ainda que não expressamente, por uma concepção de instituição como sinônimo de norma formalizada, por meio da estrutura jurídica. Diante disso, entendemos que as diretrizes epistemológicas aqui adotadas conduziam a uma outra abordagem teórico-metodológica, fundamentada no modelo analítico de Edelman e Suchman (1997).

De acordo com os autores, a análise sociológica das relações entre a esfera jurídica e as organizações sociais se estabelece pela triangulação de três elementos: (i) a perspectiva metateórica; (ii) a dimensão do ambiente legal sobre a qual se dá a análise; (iv) a direção causal proposta na delimitação do objeto de estudo. O primeiro se desdobra em dois eixos epistemológicos: (i) o das abordagens materialistas e (ii) o das abordagens culturalistas. A leitura materialista tem como premissas centrais as noções de que as práticas organizacionais têm como fundamento a racionalidade com respeito a fins e de que as leis constituem um "sistema de incentivos e coerções" que podem influenciar as referidas práticas na medida em que possam contribuir para os objetivos e metas das organizações. Como resultado, entende que a observância, ou não, das normas legais se orienta por um cálculo racional que considera a possibilidade de burlá-las na hipótese de o custo, em caso de flagrante de uma eventual ação irregular, ser menor do que o benefício obtido em virtude de tal irregularidade. Os estudos culturalistas, por sua vez, concebem as regras cristalizadas em uma dada cultura como o eixo central de orientação das ações levadas a efeito no interior das organizações, de modo que a legislação é aqui tomada, sobretudo, como um "sistema de princípios morais". De acordo com Edelman e Suchman (1997), são justamente as pesquisas que se baseiam nos pressupostos da vertente sociológica do neoinstitucionalismo as mais representativas das abordagens culturais. Sendo assim, considerando os pressupostos que orientam a consecução deste trabalho, pareceu-nos adequado analisar as modificações legislativas efetuadas em razão da realização dos megaeventos esportivos no Brasil a partir da tipologia analítica elaborada pelos autores.

Estabelecido, pois, que efetuamos uma abordagem culturalista do problema do qual aqui nos ocupamos, encontramo-nos em condições de prosseguir em direção aos outros dois elementos que compõem a triangulação teórico-metodológica do modelo de análise ora discutido. No que diz respeito ao ambiente legal, cabe registrar que os autores o subdividem em três dimensões: (i) 
${ }^{5}$ Diante das premissas sobre as quais vimos construindo esse artigo, reportar-nos-emos, daqui em diante, somente às abordagens culturalistas. Para um aprofundamento sobre as perspectivas materialistas, sugerimos a consulta direta à análise de Edelman e Suchman (1997). ambiente legal facilitador; (ii) ambiente legal regulatório e (iii) ambiente legal constitutivo. $\mathrm{O}$ primeiro se refere à condição instrumental das normas legais, que servem aos gestores das organizações conforme contribuem para o alcance de suas metas. A legislação se apresenta, aqui, em um papel predominantemente passivo, sendo, essencialmente, uma espécie de arena na qual diferentes jogadores (os representantes das organizações) desempenham um papel ativo no jogo que ali se desenvolve. No ambiente legal regulatório há um maior equilíbrio entre os papeis da legislação e das organizações, sendo que a primeira aparece como um sistema coercitivo, que atua na vida das organizações através da imposição de imperativos sociais. Por fim, o ambiente legal constitutivo é aquele em que são definidos os elementos basilares das formas e relações intra e inter-organizacionais. Apresenta um enraizamento cultural mais profundo do que as duas primeiras dimensões, e atua mais significativamente na construção de diversos atores organizacionais, bem como na relação que esses atores estabelecem entre si. Isso porque nele se originam categorias de definição, tomadas como "certas", que permitem aos indivíduos identificar e tornar conhecidos os elementos que compõem o universo social de que fazem parte. Em virtude de seus pressupostos, as abordagens culturalistas ${ }^{5}$ se concentram no modo como a legislação contribui para construir e legitimar a estrutura das organizações, inspirar e delinear sua cultura interna. Assim sendo, se dedicam, sobretudo, às dimensões regulatória e constitutiva do ambiente legal.

O terceiro componente da triangulação teórico-metodológica acima referida é a direção causal, desdobrado em três tendências analíticas distintas: (i) a que concebe a lei como variável independente e as práticas organizacionais como variáveis dependentes, ou seja, que parte do entendimento de que a legislação determina as ações efetuadas pelas organizações; (ii) a que toma a lei como variável dependente e as práticas organizacionais como variáveis independentes; (iii) a que pressupõe a existência de uma influência mútua e dinâmica entre a lei e as práticas organizacionais.

No âmbito das abordagens culturalistas, no qual se inscreve o presente trabalho, a análise das dimensões regulatória e constitutiva do ambiente legal podem operar com quaisquer das três direções causais apontadas por Edelman e Suchman (1997), a depender do recorte analítico que compõe o objeto de estudo. Assim sendo, cumpre registrar o modo como se constitui a triangulação dos elementos propostos pelos autores em nossa pesquisa, cuja finalidade, conforme já mencionado anteriormente, é identificar os efeitos institucionais gerados pelas alterações legislativas efetuadas pelo governo federal brasileiro em virtude da realização da Copa de 2014 e dos Jogos Olímpicos de 2016. Tal problemática envolve tanto a dimensão regulatória, dado que tem por objeto os institutos jurídicos, anteriores e construídos especialmente para o evento, que regulamentam as relações que se desenvolvem no universo social em que se dá a organização de tais eventos, quanto a dimensão constitutiva do ambiente legal, na medida em que se propõe a identificar efeitos institucionais cujo enraizamento cultural seja mais profundo. Desse modo, optamos pelo desdobramento da discussão em dois movimentos analíticos.

O primeiro aborda a influência das práticas e procedimentos organizacionais no processo de criação e/ou alteração da legislação, ou, em outros termos, tomando aquelas como variáveis independentes, capazes de explicar esta última, enfatizando a dimensão regulatória do ambiente legal. Como vimos, parcialmente, na primeira e segunda seções do texto, as ações das organizações envolvidas na realização dos megaeventos esportivos, quais sejam, a FIFA, o COI e suas associadas em território nacional, como a CBF, o COB e os Comitês Organizadores Locais, respectivamente, da Copa do Mundo e dos Jogos Olímpicos influenciaram significativamente o processo que culminou nas alterações legislativas promovidas em seu nome. Ao longo das 
${ }^{6}$ Tradução livre, efetuada pelos autores, do original: "The two emerge in tandem, and as the underlying belief system permeates both the legal and the organizational worlds, the boundaries between these realms become increasingly ambiguous" (Edelman \& Suchman 1997, p.502). últimas décadas, essas entidades formataram, progressivamente, a cobertura jurídico-institucional de que precisam gozar nos diferentes países que sediam os seus eventos, para que pudessem alcançar seus respectivos objetivos internos. Contudo, tal formatação, ainda que pouco flexível, somente se encontra em condições de se efetivar se as organizações que integram os poderes públicos dos países/cidades que postulam a recepção dos referidos eventos a afiançarem, adaptando os seus respectivos aparatos legislativos às demandas oriundas das práticas das aludidas organizações. E isso ocorre na medida em que se estabelece um intercurso permanente de informação e intercâmbio profissional entre os atores que se encontram no universo que demanda e a que se destina a regulamentação e as instituições políticas que têm a prerrogativa de estabelecer os novos mecanismos de regulação, que criam, no caso em análise, as excepcionalidades legais que conformem o ordenamento jurídico nacional às necessidades das entidades organizadoras dos megaeventos esportivos.

E por que os governantes aceitam essas condições, ainda que estejam em desacordo com a estrutura jurídica de sua própria sociedade e que possam, no limite, suscitar questionamentos sobre uma fortuita renúncia à soberania nacional? É indubitável que a popularidade e a mobilização social geradas por tais eventos ocupariam um lugar central em uma eventual resposta a essa indagação. Entretanto, o que é relevante assinalar é que temos aqui um exemplo característico da capacidade que as organizações em questão possuem de exercer influência na criação e/ou alteração da legislação, especialmente através da interlocução e do compartilhamento de um "sistema de crenças" com os legisladores. Cabe estabelecer aqui uma breve ressalva, na medida em que afirmar que as práticas e procedimentos das organizações causam a formulação das regras jurídicas, ou vice-versa, consiste em uma abordagem bastante simplista da questão. Isso porque "ambos emergem em conjunto, e como o sistema de crenças subjacentes permeia tanto o mundo legal quanto o organizacional, [é preciso ter em conta que] as fronteiras entre ambos se tornam progressivamente ambíguas"6 (Edelman \& Suchman 1997, p.502). No caso em tela, isso representa a perspectiva de que os megaeventos esportivos produzem benefícios de tal sorte ao país-sede que quaisquer esforços para recebê-los seriam justificados, na medida em que se apresentam como "naturais" e "inevitáveis" - no sentido de que somente com as alterações legislativas será possível conquistar, de maneira efetiva, o "direito" de sediar tais eventos e, por conseguinte, os benefícios de sua realização -, incluído aí o ajuste "excepcional" dos mecanismos de regulação operantes no país (candidato a) sede.

As considerações até aqui efetuadas ainda se encontram no plano das condições políticas e sociais que permitiram que as alterações legislativas promovidas pelo governo federal para a realização dos megaeventos esportivos no país pudessem se materializar. Contudo, naquilo que interessa mais diretamente à presente análise, os efeitos institucionais que o novo quadro legal vem produzindo nas relações sociais, é necessário desdobrar a reflexão sobre a dimensão regulatória conforme os diplomas legislativos consultados. As situações excepcionais criadas pelo Ato Olímpico e pela Lei Geral da Copa tendem a produzir efeitos relativamente restritos, apenas circunscritos ao processo de realização dos eventos esportivos, especialmente se considerarmos que a vigência de ambos se encerra tão logo estejam esgotadas, respectivamente, as etapas da organização dos Jogos Olímpicos de 2016 e da Copa do Mundo de 2014. No caso de ambos, o que nos parece constituir matéria para investigação diz respeito a eventuais efeitos que a sua instituição pode produzir no âmbito da dimensão constitutiva do ambiente legal. Dito de outra maneira, trata-se de inferir como, e em que medida, o poder conferido às entidades esportivas internacionais, de exigir (e conseguir) que um Estado-nação suspenda as normas de seu ordenamento jurídico, conferindo ao esporte e suas respectivas 
organizações um lugar "acima da lei", tende a produzir efeitos "de fundo", ou seja, impactos de natureza cognitiva nas relações Estado-sociedade, em se tratando de matéria esportiva, no longo prazo.

Parece-nos, contudo, que a lei que instituiu o RDC demanda uma abordagem distinta, visto que a criação dessa figura jurídica não se deu por influência das práticas e procedimentos oriundos das entidades esportivas internacionais, cristalizados em um modelo de ação que se transmutou em condicionalidade imposta pela FIFA ou pelo COI aos postulantes a sediar os eventos esportivos sob seu controle. Nesse caso, o que observamos foi uma apropriação simbólica dessas condicionalidades, que restaram como justificativa do processo legislativo de uma matéria que não integrava o seu conteúdo original. Essa transferência simbólica se sustentou, retoricamente, na eficiência administrativa que, de acordo com tal construção cognitiva, seria demandada pela realização da Copa do Mundo e dos Jogos Olímpicos. De fato, é corrente a representação dos megaeventos esportivos como uma complexa questão, para a qual o Estado brasileiro deve produzir respostas de forma mais eficiente possível. E a eficiência, aqui, consiste na adoção de quaisquer medidas necessárias à sua realização dentro dos padrões estabelecidos pela FIFA e pelo COI, o que justificaria a tomada de medidas excepcionais e urgentes pelos órgãos governamentais. Ademais, essa simbologia da eficiência é tanto mais potencializada conforme se dissemina a ideia de que o que está em jogo não é apenas a avaliação que a própria sociedade brasileira pode fazer de um eventual fracasso do governo em atender às referidas demandas, mas sim, e sobretudo, a avaliação do país realizada por diversos organismos internacionais.

Setores acadêmicos também contribuem para a difusão de tais ideias, dado que argumentam em favor da aplicação do RDC para o alcance de maior eficiência administrativa dos processos de licitação de bens e serviços correlatos aos megaeventos esportivos. Um exemplo de tal postura pode ser encontrado na análise de Oliveira e Freitas (2011) que, ao comparar o RDC com a Lei 8.666/93, sustenta que o excesso de formalismo desta última tende a acarretar prejuízos para a administração pública e, por conseguinte, para a sociedade. Nesse sentido, esses autores propõem a seguinte questão: “Afinal, o que poderia motivar mais a instituição de um novo regime de contratações públicas [...] do que a necessidade de viabilizar a execução de obras de infraestrutura para a realização dos eventos desportivos que serão realizados no país [...]?" (Oliveira \& Freitas 2011, p.2). Trata-se de uma questão pertinente porque, de acordo com o encadeamento lógico construído, a relevância social atribuída a esses eventos legitima o afastamento das normas que disciplinam a licitação pública no país e a criação de nova modalidade licitatória. E essa legitimidade social é tão profunda que os autores defendem a manutenção do RDC para a realização dos megaeventos esportivos, mesmo no caso de uma eventual declaração de inconstitucionalidade da lei que o criou.

A lei do RDC também diferiu do Ato Olímpico e da Lei Geral da Copa por outra razão: sua aprovação não interessa apenas às instituições esportivas e políticas mencionadas anteriormente, mas principalmente às empresas fornecedoras de bens e serviços ao Estado, com destaque para aquelas que integram o setor de atividade econômica da construção civil. O que constatamos, nesse caso, é a influência de outros setores organizacionais na elaboração do novo aparato legislativo. Tal influência se revestiu, sobretudo, de um caráter cognitivo, haja vista que atuou não apenas no delineamento de novos dispositivos legais, mas principalmente na consolidação de uma construção simbólica que os justificasse. Há que se observar, aqui, que a discussão sobre a (in)eficiência e consequente necessidade de simplificação das regras e procedimentos licitatórios já se apresentavam na pauta de discussões políticas em nossa sociedade, de modo que as propostas de modificação da Lei 8.666/93 não eram de todo 
desconsideradas pelo debate público. Porém, em virtude de interesses políticos e econômicos que essa matéria envolve, o cenário que se desenhava no horizonte era de um longo e custoso processo legislativo para que a mudança da Lei de Licitações chegasse a termo no Congresso Nacional. Diante disso, a influência cognitiva dos megaeventos esportivos para a elaboração do RDC se deu, fundamentalmente, pela possibilidade, aberta ao governo federal, de abreviar a discussão congressual, aprovando-a em caráter de urgência. Em outras palavras, a realização da Copa de 2014 e dos Jogos de 2016 permitiu que a mudança (quase) imediata das normas relativas à licitação pública no país fosse admitida como algo "natural" e inevitável.

Ainda no tocante às diferenças da lei do RDC em relação ao Ato Olímpico e à Lei Geral da Copa, cumpre registrar que, enquanto os dois últimos foram sancionados com um prazo de vigência definido, a primeira entrou em vigor por tempo indeterminado. Considerando o teor do Artigo $1^{\circ}$ da Lei 12.462/2011, poder-se-ia supor que, encerradas as obras e serviços vinculados aos megaeventos esportivos, também findaria a validade desse diploma legislativo. Todavia, o que ocorreu, no período que sucedeu à sua sanção, foi a expansão progressiva de sua abrangência, de modo que o RDC passou a contemplar obras de engenharia vinculadas a setores da administração pública que não estavam relacionadas com o seu escopo original, conforme podemos verificar na Tabela 1 , abaixo.

Tabela 1 - Evolução da Abrangência do Regime Diferenciado de Contratações Públicas no Ordenamento Jurídico (Brasil, 2011-2014)

\begin{tabular}{|c|c|}
\hline Ato & Disposições \\
\hline Lei $12.462(04 / 08 / 2011)$ & 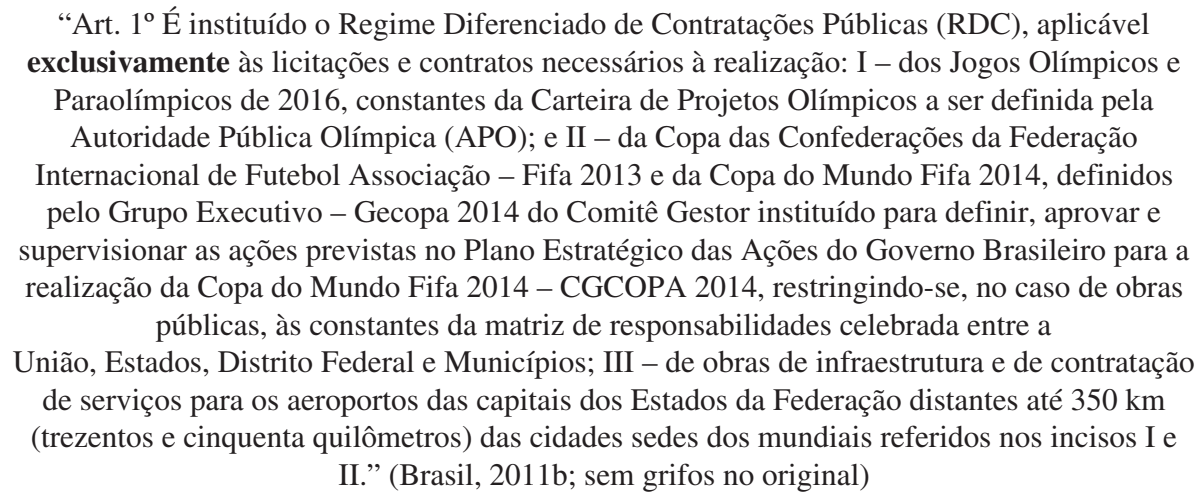 \\
\hline Lei $12.688(18 / 07 / 2012)$ & $\begin{array}{l}\text { "Art. 28. Os arts. } 1^{\circ} \text { e } 43 \text { da Lei } n^{\circ} 12.462 \text {, de } 4 \text { de agosto de } 2011 \text {, passam a vigorar com as } \\
\text { seguintes alterações: 'Art. } 1^{\circ}[\ldots . .] \text { IV - das ações integrantes do Programa de Aceleração do } \\
\text { Crescimento'." (Brasil, 2012b; sem grifos no original) }\end{array}$ \\
\hline Lei $12.722(03 / 10 / 2012)$ & $\begin{array}{l}\text { “Art. 14. O art. } 1^{\circ} \text { da Lei } n^{\circ} 12.462 \text {, de } 4 \text { de agosto de } 2011 \text {, passa a vigorar com a seguinte } \\
\text { redação: 'Art. } 1^{\circ}[\ldots] \S 3^{\circ} \text { Além das hipóteses previstas no caput, o RDC também é aplicável } \\
\text { às licitações e contratos necessários à realização de obras e serviços de engenharia no } \\
\text { âmbito dos sistemas públicos de ensino'." (Brasil, 2012c; sem grifos no original) }\end{array}$ \\
\hline Lei $12.745(19 / 12 / 2012)$ & $\begin{array}{l}\text { "Art. } 4^{\circ} \mathrm{O} \text { art. } 1^{\circ} \text { da Lei } 12.462 \text {, de } 4 \text { de agosto de } 2011 \text {, passa a vigorar com a seguinte } \\
\text { alteração: 'Art. } 1^{\circ}[\ldots] \text { V- das obras e serviços de engenharia no âmbito do Sistema Único } \\
\text { de Saúde - SUS'." (Brasil, 2012d; sem grifos no original) }\end{array}$ \\
\hline Lei $12.980(28 / 05 / 2014)$ & $\begin{array}{l}\text { "Art. } 1^{\circ} \text { A Lei } \mathrm{n}^{\circ} 12.462 \text {, de } 4 \text { de agosto de } 2011 \text {, passa a vigorar com as seguintes alterações: } \\
\text { "Art. } 1^{\circ}[\ldots] \text { V - das obras e serviços de engenharia para construção, ampliação e reforma } \\
\text { de essabelecimentos penais e unidades de atendimento socioeducativo [...]" (Brasil, 2014b; } \\
\text { sem grifos no original). }\end{array}$ \\
\hline
\end{tabular}

Fonte: Os autores, a partir de Brasil (2011b, 2012b, 2012c, 2012d, 2014b). 
Os dados apresentados nesse quadro informativo nos indicam que, sendo criado excepcionalmente para a licitação de obras e serviços vinculados à organização dos megaeventos esportivos no Brasil, o RDC se tornou igualmente aplicável às obras de engenharia do Sistema Único de Saúde, dos Sistemas Públicos de Ensino, do Programa de Aceleração do Crescimento - que é responsável, entre outros, pelos investimentos em infraestrutura efetuados pelo governo federal em áreas como transporte, energia e recursos hídricos (Brasil 2014a) - e, finalmente, dos estabelecimentos penais e unidades de atendimento socioeducativo (idem). Assim sendo, o RDC encontra-se, atualmente, em condições jurídicas de substituir, virtualmente, a Lei 8.666/93 na quase totalidade dos processos licitatórios de contratação pública de obras de engenharia, não por acaso as que envolvem maior dispêndio de recursos pelo Estado. Desse modo, parece lícito considerar que a realização da Copa do Mundo e dos Jogos Olímpicos no país desempenhou um papel relevante na conformação do atual ambiente regulatório das licitações públicas no país.

O segundo movimento analítico que a construção do objeto desse trabalho a partir das premissas do neoinstitucionalismo sociológico, aqui adotadas, exigiu foi a discussão sobre o impacto que as alterações legislativas exerceram (e exercem) sobre discursos, prática, procedimentos e crenças das organizações envolvidas no processo. Trata-se de um enfoque analítico que se orienta para a dimensão constitutiva do ambiente legal, que tem por fim último identificar o modo como a legislação influencia decisivamente tanto na composição quanto no funcionamento das organizações. Como vimos, as abordagens culturalistas tomam os aparatos legislativos como conjunto de ideias e noções que servem para conferir sentido aos acontecimentos do mundo social, de modo que sua principal preocupação reside na recomposição dos esquemas de compreensão, estruturados juridicamente, que contribuem para a conformação de práticas e procedimentos organizacionais. Isso significa tomar a legislação como variável independente, e as ações tomadas no interior das organizações como variáveis dependentes. Contudo, é preciso reconhecer que os efeitos da criação e/ou modificação de dispositivos legais tendem a não aparecer de imediato, sendo construídos aos poucos como "crenças cognitivas e normativas", que são incorporadas de maneira progressiva à cultura organizacional, conforme pontuam Edelman e Suchman (1997).

Esse entendimento produz uma relevante implicação metodológica, na medida em que, sendo um processo lento e gradual, apresenta-se em condições de verificação somente por meio de uma abordagem analítica que transcorra por longo período de tempo. No caso em análise, podemos citar como exemplo a assertiva segundo a qual o sigilo sobre o orçamento estimado favorecerá a disseminação de práticas de corrupção para a compra (e venda) de informações privilegiadas por alguns dos licitantes. Trata-se de uma proposição que somente poderá ser confrontada após a cristalização dessa nova modalidade licitatória no interior das organizações públicas e privadas envolvidas. Para que tal argumento se sustente, contudo, parece-nos necessário coletar informações através de um estudo de longo prazo, o que foge ao escopo do presente trabalho. Isso porque nosso propósito é identificar o que denominamos, na seção introdutória, de legados institucionais pré-eventos, dada a possibilidade de levantamento de dados que pudessem servir de sustentação empírica à análise que procuramos aqui empreender. Consideramos, pois, que para contemplar os efeitos institucionais da realização dos megaeventos esportivos na dimensão constitutiva do ambiente legal é preciso aprofundar e diversificar as pesquisas sobre essa temática. 


\section{Conclusões}

A escolha do Brasil para sediar dois megaeventos esportivos em um intervalo de apenas dois anos trouxe a projeção de uma série de benefícios para o país, referidos sob a denominação comum de "legados", termo utilizado para designar os (esperados) efeitos "positivos" que a organização de tais eventos possam propiciar ao local que os recepciona. Importante elemento retórico, tanto das entidades esportivas quanto dos governos que buscam sediá-los, o discurso sobre os legados também adquiriu impulso na literatura acadêmica. A hoje vasta produção sobre o tema aborda, predominantemente os seguintes aspectos, como os que recebem maior impacto da organização dos megaeventos esportivos em dada sociedade: (i) adesão da população às práticas esportivas; (ii) impulso à atividade econômica; (iii) bem-estar da população; (iv) regeneração urbana; $(v)$ imagem internacional do país.

Examinamos, neste trabalho, uma dimensão ainda pouco explorada pela literatura sobre legados de megaeventos, qual seja, a dos impactos sobre as instituições, aos quais denominamos legados institucionais, tomando como ponto de partida as alterações legislativas efetuadas pelo governo federal brasileira em virtude da realização da Copa do Mundo de 2014 e dos Jogos Olímpicos de 2016 no país. Nesse sentido, estabelecemos, inicialmente, um retrospecto dos requisitos impostos pela FIFA e pelo COI aos postulantes à sede de seus respectivos eventos. Em seguida, indicamos as principais modificações do quadro legislativo nacional para atender aos referidos requisitos, tomando como principais fontes de consulta as Leis 12.039/2009; 12.462/2011 e 12.663/2012. Finalmente, embasando-nos nos pressupostos teóricos do neoinstitucionalismo sociológico, efetuamos uma análise dos impactos das alterações legislativas em questão nas dimensões regulatória e constitutiva do ambiente legal, tais como as definem Edelman e Suchman (1997).

Diante das premissas teóricas adotas, entendemos necessário desdobrar a discussão sobre os efeitos institucionais da realização dos megaeventos em dois movimentos analíticos. Primeiramente, buscamos identificar a influência que as organizações esportivas e políticas envolvidas com a realização dos megaeventos esportivos exerceram na conformação dos novos aparatos legislativos (modificados em relação à legislação pré-existente).

No que diz respeito à dimensão regulatória do ambiente legal, verificamos que os megaeventos esportivos exerceram uma influência normativa, tanto na elaboração do Ato Olímpico quanto da Lei Geral da Copa, e também simbólica, no tocante à lei que instituiu o RDC. Essas alterações, contudo, comportaram-se de maneira diferente na dimensão legal em questão, na medida em que as duas primeiras não resultaram na produção de efeitos legais para além da realização dos eventos, ao passo que a última alastrou seu leque de abrangência no ambiente regulatório de diferentes setores da sociedade. O segundo movimento analítico que se apresentou como necessário foi a discussão de como, e em que medida, as alterações legislativas efetuadas em razão dos megaeventos esportivos impactam práticas e procedimentos no interior das organizações envolvidas nos processos que receberam a nova regulamentação. Assumindo o entendimento de que esses impactos não se entregam de imediato, mas que são progressiva e silenciosamente elaborados, como "crenças cognitivas e normativas", no âmbito da cultura organizacional, vislumbramos a necessidade da elaboração de uma agenda de pesquisa que, através de um trabalho de consistente verificação empírica, possa contemplar a cristalização e internalização, em médio e longo prazos, das normas legais criadas sob a justificativa da organização dos megaeventos esportivos no país. 
Renata Maria Toledo (remariatoledo@ hotmail.com) é licenciada em Educação Física pela Universidade Federal do Paraná e doutoranda do Programa de Pós-Graduação em Sociologia na mesma universidade, contando com financiamento da Capes. Realizou estágio de pesquisa na University of Birmingham, Reino Unido, financiada pelo Programa Interinstitucional de Doutorado Sanduíche no Exterior da Capes. Vínculo institucional: Programa de Pós-Graduação em Sociologia, UFPR, Curitiba, PR, Brasil.

Jonathan Grix (j.grix @ bham.ac.uk) é Doutor em German Politics pela Universidade de Birmingham, Reino Unido, e Reader in Sport Policies and Politics na School of Sport and Exercise da mesma universidade. Vínculo institucional: School of Sport, Exercise and Rehabilitation, University of Birmingham, Birmingham, West Midlands, United Kingdom.

Maria Tarcisa Silva Bega (mtarcisa@hotmail.com) é Doutora em Sociologia pela Universidade de São Paulo (USP) e Professora do Departamento de Ciência Política e Sociologia da mesma universidade. Vínculo institucional: Departamento de Ciência Política e Sociologia, UFPR, Curitiba, PR, Brasil.

\section{Referências}

Agamben, G., 2004. Estado de exceção. São Paulo: Boitempo.

Almeida, B.S. \& Marchi Jr, W., 2014. O Brasil e os megaeventos esportivos: os subsídios da política externa. Motrivivência, 26(42), pp.13-26. DOI: 10.5007/2175-8042.2014v26n42p13.

Almeida, B.S.; Mezzadri, F.M. \& Marchi Jr., W., 2009. Considerações sociais e simbólicas sobre sedes de megaeventos esportivos. Motrivivência, 32-33, pp.178-192. DOI: 10.5007/2175-8042.2009n32-33p178.

Alves, R.O., 2012. O Estado, a multidão e os conflitos urbanos. Desenvolvimento regional em debate, 2, pp.111-123.

Andrade, R.B., 2012. Uma visão geral sobre o regime diferenciado de contratações públicas: objeto, objetivos, definições, princípios e diretrizes. Informativo Justen, Pereira, Oliveira e Talamini, 60.

Bachur, J.P., 2005. Federalismo fiscal, atribuições fiscais constitucionais e equalização regional: EUA, Alemanha e Brasil em perspectiva comparada. Revista do Serviço Público, 56(4), pp.377-401.

Benedicto, D.B.M., 2008. Desafiando o coro dos contentes: vozes dissonantes no processo de implementação dos Jogos Pan-Americanos, Rio 2007. Dissertação de Mestrado. Rio de Janeiro: Universidade Federal do Rio de Janeiro.

Bernabé, A.P. \& Starepravo, F.A., 2014. Megaeventos esportivos: o desenvolvimento do legado esportivo educacional. Pensar a prática, 17(2), pp.456-471.

Betti, M., 2009. Copa do Mundo e Jogos Olímpicos: inversionalidade e transversalidades na cultura esportiva e na Educação Física escolar. Motrivivência $232-33$, pp.16-27. DOI: 10.5007/2175-8042.2009n32-33p16.

Black, D., 2007. The Symbolic Politics of Sport Mega-Events: 2010 in comparative perspective. Politikon, 34(3), pp.261-276. DOI: $10.1080 / 02589340801962536$.

Bottura, A.C.L., 2014. O paradigma da cidade global e as olimpíadas do Rio de Janeiro. Oculum ensaios, 11(1), pp.119-135.

Braathen, E.; Sørbøe, C.M. \& Mascarenhas, G., 2014. BRICS, megaeventos esportivos e o Rio de Janeiro como uma 'cidade de exceção'. Tensões Mundiais, 10(18-19), pp.327-362.

Cardoso, A.G., 2012. O regime diferenciado de contratações públicas: a questão da publicidade do orçamento estimado. Informativo Justen, Pereira, Oliveira e Talamini, 60.

Castro, D.G., 2013. Governança urbana empreendedorista e megaeventos esportivos. Geo UERJ, v.1 (24), pp.37-60. DOI: 10.12957/geouerj.2013.5058.

Chalip, L., 2004. Beyond Impact: A general model for host community event leverage. In B.W. Ritchie \& D. Adair, eds. Sport Tourism: Interrelationships, impacts and issues. Clevedon: Channel View Publications.

2006. Towards Social Leverage of Sport Events. Journal of Sport and Tourism, 11(2), pp.109-127. DOI: $10.1080 / 14775080601155126$.

Cortes, S.V. \& Lima, L.L., 2012. A contribuição da sociologia para a análise de políticas públicas. Lua Nova, 87, pp.33-62. DOI: 10.1590/S0102-64452012000300003.

Cruz, M.C.M., 2010. Do "Mississipi Carioca” ao "Estádio Voador": forjando espaços de legitimação na indiferença. Dissertação de Mestrado. Niterói: Universidade Federal Fluminense.

DaCosta, L.P.; Corrêa, D.; Rizzuti, E.; Villano, B. \& Miragaya, A., 2008. Legados de megaeventos esportivos. Brasília: Ministério do Esporte.

Davis, J.; Thornley, A., 2010. Urban Regeneration for the London 2012 Olympics: Issues of land acquisition and legacy. City, Culture and Society, 1(2), pp.89-98. DOI: 10.1016/j.ccs.2010.08.002.

Domingues, E.P.; Betarelli JR, A.A. \& Magalhães, A.S., 2011. Quanto vale o show? Impactos econômicos dos investimentos da Copa do Mundo 2014 no Brasil, Estudos Econômicos, 41(2), pp.409-439. DOI: 10.1590/50101-41612011000200008.

Durkheim, E., 1996. As formas elementares da vida religiosa. São Paulo: Martins Fontes.

Edelman, L.B. \& Suchman, M.C., 1997. The Legal Environments of Organizations. Annual Review of Sociology, 23, pp.479-515. DOI: 10.1146/annurev.soc.23.1.479.

Figuerôa, K.M.; Sevegnani, P.; Mezzadri, F.M. \& Silva, M.M., 2014. Planejamento, ações e financiamento par o esporte em tempos de megaeventos. Motrivivência, 26(42), pp.55-71. DOI: 10.5007/2175-8042.2014v26n42p55.

Grix, J. \& Lee, D., 2013. Soft Power, Sports Mega-Events and Emerging States: The lure of the politics of attraction. Global Society, 27(4), pp.521-436. DOI: 10.1080/13600826.2013.827632. 
Hall, P.A. \& Taylor, R.C.R., 2003. As três versões do neo-institucionalismo. Lua Nova, 58, pp.193-223. DOI: 10.1590/S0102-64452003000100010.

Hayes, G. \& Horne, J., 2011. Sustainable Development, Shock and Awe? London 2012 and Civil Society. Sociology, 45(5), pp.749-764. DOI: 10.1177/0038038511413424.

Horne, J., 2007. The Four "Knowns" of Sport Mega-Events. Leisure Studies, 26(1), pp.81-96. DOI: $10.1080 / 02614360500504628$.

Houlihan, B. \& Green, M., eds, 2008. Comparative Elite Sport Development: Systems, structures and public policy. Oxford: Butterworth-Heinemann.

Kenelly, J. \& Watt, P., 2011. Sanitizing Public Space in Olympic Host Cities: The spatial experiences of marginalized youth in 2010 Vancouver and 2012 London. Sociology, 45(5), pp.765-781. DOI: 10.1177/0038038511413425.

Manzenreiter, W., 2010. The Beijing Games in the Western Imagination of China: The weak power of soft power. Journal of Sport and Social Issues, 34(1), pp.29-48. DOI: 10.1177/0193723509358968.

Mascarenhas, F., 2012. Megaeventos esportivos e Educação Física: alerta de tsunami. Movimento, 18(1), pp.39-67.

Matos, A.S.M.C., 2014a. A Copa da exceção no Tribunal da Teoria Pura do Direito. Revista Direito e Práxis, 5(8), pp.49-75. DOI: $10.12957 /$ dep.2014.7970.

,2014b. Hans Kelsen, Estado de exceção e Copa do Mundo no Brasil, Cuadernos Electrónicos de Filosofia del Derecho, 29, pp.1-23.

Miagusko, E., 2012. Antes da Copa, depois do Pan: o Rio de Janeiro na era dos megaeventos esportivos. Civitas, 12(2), pp.395-408. DOI: 10.15448/1984-7289.2012.2.11935.

Oliveira, N.G., 2012. O poder dos Jogos e os jogos do poder: os interesses em campo na produção de uma cidade para o espetáculo esportivo. Tese de Doutorado. Rio de Janeiro: Universidade Federal do Rio de Janeiro.

Oliveira, R.C.R. \& Freitas, R.V., 2011. O regime diferenciado de contratações públicas (RDC) e a administração de resultados. Revista Eletrônica de Direito Administrativo Econômico, 27.

Ouriques, N., 2009. Olimpíada 2016 - o desenvolvimento do subdesenvolvimento. Motrivivência, 32-33, pp.126-155. DOI: $10.5007 / 2175-8042.2009$ n32-33p126A.

Proni, M.W., 2009. Observação sobre os impactos econômicos esperados dos Jogos Olímpicos de 2016. Motrivivência, 32-33, pp.49-70. DOI: 10.5007/2175-8042.2009n32-33p49.

Raco, M. \& Tunney, E., 2010. Visibilities and Invisibilities in Urban Development: Small business communities and the London Olympics 2012. Urban Studies, 47(10), pp.2069-2091. DOI: 101177/0042098009357351.

Reis, A.C.; Sousa-Mast, F.R. \& Gurgel, L.A., 2014. Rio 2016 and the Sport Participation Legacies. Leisure Studies, 33(5), pp.437-453. DOI:10.1080/02614367.2012.

Resende, C.A., 2010. O esporte na política externa do governo Lula: o importante é competir? Boletim Meridiano 47, 11(122), pp.35-41.

Rezende, F., 1995. Federalismo fiscal no Brasil, Revista de Economia Política, 15(3), pp.5-17.

Rodrigues, A.M., 2013. Os megaeventos na produção e reprodução do espaço urbano. Geotextos, 9(2), pp.13-25.

Romera, L.A., 2014. Copa do Mundo e cerveja: impactos intangíveis de um megaevento. Movimento, 20(2), pp.775-798.

Rubio, K., 2009. O legado educativo dos megaeventos esportivos. Motrivivência, 32-33, pp.71-88. DOI: 10.5007/21758042.2009n32-33p71.

Sá, M.R.A., 2012. As diretrizes para as licitações e contratos realizados em conformidade com o RDC. Informativo Justen, Pereira, Oliveira e Talamini, 60.

Sánchez, F. \& Broudehoux, A.M., 2013. Mega-Events and Urban Regeneration in Rio de Janeiro: Planning in a state of emergency. International Journal of Urban Sustainable Development, 5(2), pp.132-153. DOI: 10.1080/19463138.2013.839450.

Schausteck de Almeida, B. \& Marchi Junior, W., 2013. The Brazilian Media and the Selection of Rio de Janeiro to host the 2016 Olympic and Paralympic Games. Przeglad Socjologiczny, 3, pp.71-84.

Souza, J. \& Marchi Jr., W., 2010. Os "legados" dos megaeventos esportivos no Brasil: algumas notas e reflexões. Motrivivência, 34, p.245-255. DOI: 10.5007/2175-8042.2010n34p245.

Vainer, C., 2011. Cidade de exceção: reflexões a partir do Rio de Janeiro. In Encontro Nacional da ANPUR. Rio de Janeiro.

Van Ham, P., 2001. Rise of the Brand State: The postmodern politics of image and reputation. Foreign affairs, 80(5), pp.2-6. DOI: $10.2307 / 20050245$.

Weber, M., 2001. Metodologia das ciências sociais. V. 2. $3^{\mathrm{a}}$ ed. São Paulo: Cortez.

Weed, M. et al., 2009. A Systematic Review of the Evidence Base for Developing a Physical Activity and Health Legacy from the London 2012 Olympic and Paralympic Games. Canterbury: Canterbury Church University.

\section{Outras fontes}

Brasil, 1993. Lei $n^{\circ}$ 8.666, de 21 de junho de 1993. Disponível em http://www.planalto.gov.br/ccivil_03/18666cons.htm. Acesso em: 20 fev. 2013.

Brasil, 1996. Lei $n^{\circ}$ 9.279, de 14 de maio de 1996. Disponível em http://www.planalto.gov.br/ccivil_03/leis/19279.htm. Acesso em: 20 fev. 2013.

Brasil, 2002a. Lei $n^{o}$ 10.406, de 10 de janeiro de 2002. Disponível em http://www.planalto.gov.br/ccivil_03/leis/2002/110406.htm. Acesso em: 20 set. 2015. 
Brasil, 2002b. Lei $n^{\circ} 10.520$, de 17 de julho de 2002. Disponível em http://www.planalto.gov.br/ccivil_03/leis/2002/110520.htm. Acesso em: 20 fev. 2013.

Brasil, 2003. Lei $n^{\circ} 10.671$, de 15 de maio de 2003. Disponível em http://www.planalto.gov.br/ccivil_03/leis/2003/110.671.htm. Acesso em: 20 set. 2015.

Brasil, 2007. Discurso do Presidente da República - Luiz Inácio Lula da Silva - na cerimônia de anúncio do Brasil como sede da Copa do Mundo de 2014. Disponível em http://biblioteca.presidencia.gov.br/ex-presidentes/luiz-inacio-lula-da-silva/discursos/2o-mandato/2007/2o-semestre//3 0-10-2007-discurso-do-presidente-da-republica-luiz-inacio-lula-da-silva-na-cerimonia-de-anuncio-do-brasil-como-sed e-da-copa-do-mundo-de-2014/view. Acesso em: 2 abr. 2013.

Brasil, 2009. Lei $n^{o} 12.035$, de 01 de outubro de 2009. Disponível em http://www.planalto.gov.br/ccivil_03/_ato2007-2010/2009/lei/112035.htm. Acesso em: 15 fev. 2013.

Brasil, 2011a. Constituição da República Federativa do Brasil, Texto constitucional promulgado em 5 de outubro de 1988, com as alterações adotas pelas Emendas Constitucionais $n^{\circ}$ s 1/92 a 67/2010, pelo Decreto $n^{\circ} 186 / 2008$ e pelas Emendas Constitucionais de Revisão nº 1 a 6/94. Brasília: Senado Federal.

Brasil, 2011. Lei $n^{o}$ 12.462, de 04 de agosto de 2011b. Disponível em http://www.planalto.gov.br/ccivil_03/_ato2011-2014/Lei/L12462.htm. Acesso em: 15 fev. 2013.

Brasil, 2012a. Lei $n^{o} 12.663$, de 05 de junho de 2012. Disponível em http://www.planalto.gov.br/ccivil/03/_Ato2011-2014/2012/Lei/L12663.htm. Acesso em: 15 fev. 2013.

Brasil, 2012b. Lei $n^{o} 12.688$, de 18 de julho de 2012. Disponível em http://www.planalto.gov.br/ccivil_03/_ato2011-2014/2012/Lei/L12688\#art28. Acesso em: 15 fev. 2013.

Brasil, 2012c. Lei $n^{\circ} 12.722$, de 03 de outubro de 2012. Disponível em http://www.planalto.gov.br/ccivil_03/_ato2011-2014/2012/Lei/L12722.htm. Acesso em: 15 fev. 2013.

Brasil, 2012d. Lei $n^{o} 12.745$, de 19 de dezembro de 2012. Disponível em http://www.planalto.gov.br/ccivil_03/_ato2011-2014/2012/lei/112745.htm. Acesso em: 15 fev. 2013.

Brasil, 2014a. Sobre o PAC. Disponível em http://www.pac.gov.br/sobre-o-pac. Acesso em: 8 set. 2014.

Brasil, 2014b. Lei $n^{\circ} 12.980$, de 28 de maio de 2014. Disponível em http://www.planalto.gov.br/ccivil_03/_ato2011-2014/2014/Lei/L12980.htm\#art1. Acesso em: 16 set. 2014.

COB, 2009. Dossiê de Candidatura Rio de Janeiro 2016. Disponível em http://www.rio2016.com/sites/default/files/parceiros/dossie_de_candidatura_v1.pdf. Acesso em: 12 dez. 2013.

IOC, 2008. Candidature Procedure and Questionnaire. Disponível em: http://www.olympic.org/Documents/Reports/EN/en_report_1318.pdf. Acesso em: 9 nov. 2015.

\begin{abstract}
This paper sets out to examine the institutional effects of the completion of 2014 World Cup and 2016 Olympics in Brazil. It consists of analysing the legal and institutional changes taken in order to attend the demands of the international sports organizations which control the elite sports and their respective events and, therefore, identifying the eventual impacts on the institutions of the host-country. To do so, we focus on the legal changes accomplished by Brazilian federal government to fulfil the financial, political and legal guarantees presented by both Bid Committees to the Fédération Internationale de Football Association (FIFA) and the International Olympic Committee (IOC). We carried out a documental research, emphasizing the legal rules regarding to this topic, among which it is worth mentioning the Olympic Act, the General Law of World Cup, the Differential Procurement Regime, comparing them with the prior legal framework. Then, based on sociological institutionalism and the analytical typology proposed by Edelman \& Suchman (1997) on the legal environment of organizations, we examined their institutional effects. To do so, we executed two analytical tasks: a) an examination of the influence of organizations - sporting and political - on the legislative process; b) a discussion of how, and to what extent, those legislative changes affect organizations, highlighting the constitutive dimension of the legal environment. Regarding the former, we identified institutional effects on the regulatory facet of the legal environment. It was a normative influence in the enactment of the Olympic Act and the General Law of World Cup, and a cognitive one in the enactment of the law that created the Differential Procurement Regime. With respect to the latter, it was not possible to identify institutional effects on the discourses, practices and procedures of the organizations involved in the reception of mega-events, since the effects on the constitutive facet of legal environment do not appear immediately. Therefore, it suggessed a demand for a research agenda on this topic. The result of our research contributes to the literature since it adds a new methodological approach - while academic studies commonly use an a posteriori approach, we used the notion of pre-event legacies - and a new analytical category, since it purposes the investigation of a type of legacy still unexplored by previous researches. Furthermore, it suggests the essablishment of a research agenda on this theme, which drives to the development of the literature on sports mega-events legacies.
\end{abstract}

KEYWORDS: sports megaevents; legacies; institutions; 2014 World Cup; 2016 Olympics.

License information: This is an open-access article distributed under the terms of the Creative Commons Attribution License (CC-BY-NC 4.0), which permits unrestricted use, distribution, and reproduction in any medium, provided the original work is properly cited. 